Revista Eletrônica de Direito Processual - REDP.

Rio de Janeiro. Ano 11. Volume 18. Número 1. Janeiro a Abril de 2017

Periódico Quadrimestral da Pós-Graduação Stricto Sensu em Direito Processual da UERJ

Patrono: José Carlos Barbosa Moreira. ISSN 1982-7636. pp. 118-149

www.redp.uerj.br

\title{
NOTAS SOBRE A PERENE CRISE DO PRINCÍPIO DE OBRIGATORIEDADE \\ DA AÇÃO PENAL NO ORDENAMENTO ITALIANO ${ }^{1}$
}

\section{NOTES ON THE ONGOING CRISIS OF MANDATORY PROSECUTION IN ITALIAN LAW}

Bruna Capparelli

Doutoranda em Processo Penal pela Alma Mater Studiorum Università di Bologna/Itália. bruna.capparelli2@unibo.it

orcid.org/0000-0003-1249-2658

Vinicius Gomes de Vasconcellos

Doutorando em Direito pela Universidade de São Paulo (USP), com período de sanduíche (PDSE/Capes) na Universidad Complutense de Madrid (ESP). Mestre em Ciências Criminais pela Pontifícia Universidade Católica do Rio Grande do Sul - PUCRS (2014), com bolsa integral CAPES. Pós-graduado pela Universidad de Castilla-La Mancha (ESP) (2013). Pesquisador visitante no Max Planck Institute for Foreign and International Criminal Law (2014 e 2017). Editor-chefe da Revista Brasileira de Direito Processual Penal (RBDPP) e editor-assistente da Revista Brasileira de Ciências Criminais (RBCCRIM). Professor de Direito Penal e Processual Penal das Faculdades Integradas Campos Salles (SP). vgomesv@gmail.com orcid.org/0000-0003-2020-5516

RESUMO: Este artigo pretende analisar o cenário italiano e as principais discussões relacionadas à obrigatoriedade da ação penal e à possibilidade de previsão de critérios de priorização para relativização de tal premissa. Trata-se de questão primordial diante da

\footnotetext{
${ }^{1}$ Artigo recebido em 23/03/2017 e aprovado em 19/04/2017.
} 
Revista Eletrônica de Direito Processual - REDP.

Rio de Janeiro. Ano 11. Volume 18. Número 1. Janeiro a Abril de 2017

Periódico Quadrimestral da Pós-Graduação Stricto Sensu em Direito Processual da UERJ

Patrono: José Carlos Barbosa Moreira. ISSN 1982-7636. pp. 118-149

www.redp.uerj.br

generalizada sobrecarga da justiça criminal, especialmente em razão do expressivo e há muito descrito fenômeno da expansão do direito penal. Assim, coloca-se o seguinte problema: é sustentável a ideia de uma obrigatoriedade absoluta, que determine um dever de acusação pública em todos os casos de ocorrência de um crime e de existência elementos suficientes para a sua comprovação? A partir desse estudo, sustentar-se-á que devem ser previstos espaços de racionalização de tal princípio, por meio de diretrizes parlamentares e atividades integrativas das procuradorias, com critérios distintos à exclusiva ocorrência de um crime e de elementos suficientes para a sua comprovação, regulados de um modo a poderem ser generalizáveis e controláveis, com pressupostos objetivos e taxativos, assim respeitando a necessidade de igualdade de tratamento entre os cidadãos.

PALAVRAS-CHAVE: processo penal; obrigatoriedade da ação penal; critérios de prioridade; Ministério Público; verificação da notícia de crime; processo penal italiano.

ABSTRACT: This article intends to analyze the Italian situation and the main discussions related to the principle of mandatory prosecution in criminal procedure and to the possibility of regulating criteria of prioritization to relativize that premise. This is a primordial issue considering the widespread overload of criminal justice, especially because of the expressive and long-described phenomenon of the overcriminalization. Thus, the following problem arises: Is sustainable the idea of an absolute mandatory prosecution, which establishes a duty to the public prosecution in all cases of a crime and existence of sufficient evidence to substantiate it? Based on this study, it will be argued that some criteria should be provided for rationalization of this principle, through parliamentary guidelines and integrative activities of the prosecutor's offices, with standards distinct from the exclusive occurrence of a crime and sufficient evidence to prove it, regulated in such a way as to be generalizable and controllable, with objective assumptions, thus respecting the need for equal treatment between citizens.

KEYWORDS: criminal procedure; mandatory prosecution; priority criteria; public prosecutor; investigation of notitia criminis; Italian criminal procedure. 
Revista Eletrônica de Direito Processual - REDP.

Rio de Janeiro. Ano 11. Volume 18. Número 1. Janeiro a Abril de 2017

Periódico Quadrimestral da Pós-Graduação Stricto Sensu em Direito Processual da UERJ

Patrono: José Carlos Barbosa Moreira. ISSN 1982-7636. pp. 118-149

www.redp.uerj.br

SUMÁRIO: Introdução. 1. O conceito de ação e o controle jurisdicional sobre o dever de

agir. 2. Investigações do acusador para a verificação da notícia de crime. 3. Critérios de prioridade: dados normativos, "circolari" e possíveis perspectivas. Considerações finais.

Referências bibliográficas.

\section{Introdução}

Como é notório, o princípio de obrigatoriedade da ação penal encontra consagração no art. 112 da Constituição italiana, o qual estabelece que "o ministério público tem o dever de exercer a ação penal" ${ }^{2}$. Trata-se de uma fórmula curta e incisiva, uma das disposições "mais lacônicas da Carta fundamental da republica"3 italiana. Até mesmo por esses motivos, trata-se de uma norma que encontrou múltiplas disputas interpretativas, tornando-se terreno de ásperos debates de política da justiça penal.

Existe concordância, seja na doutrina como na jurisprudência, em considerar o princípio da obrigatoriedade da ação penal uma norma instrumental, em lugar de final. A própria Corte constitucional o define como "ponto de convergência de um complexo de princípios basilares no sistema constitucional"4.

A ratio da norma é, de fato, reconduzível a três diferentes valores de status constitucional: o princípio de igualdade (art. 3), o princípio de legalidade (art. 25, inciso 2) e o princípio de independência externa (ou, também dita, "independência institucional"5) do ministério público. Os primeiros dois valores são estruturas não elimináveis do princípio, contudo não se pode dizer o mesmo em relação à independência externa: de fato, existem sistemas onde a larga confiança entre sociedade, poderes públicos e magistratura torna possível uma pacífica convivência e aceitação seja do princípio de obrigatoriedade da ação penal seja daquele de dependência do Ministério Público ao poder executivo. Tais

\footnotetext{
2 (Tradução livre).

${ }^{3}$ CHIAVARIO, Mario. L'obbligatorietà dell'azione penale: il principio e la realtà, Cassazione penale, 1993, p. 2658 s. (tradução livre). Ver também: CHIAVARIO, Mario. Profili del principio costituzionale di obbligatorietà dell'azione penale. In: CHIAVARIO, Mario, L'azione penale tra diritto e politica, Padova: Cedam, 1995, 55 s. e GIALUZ, Mitja. Art. 112. In: BARTOLI, Roberto; BIN, Roberto (org.), Commentario breve alla Costituzione, Padova: Cedam, 2008, p. 1011 s.

${ }^{4}$ Corte const., sent. 28 de janeiro de 1991, n. 88. Cassazione penale, 1992, p. 249 s.

5 Sobre isso, ver: RUSSEL, Peter H. Toward a General Theory of Judicial Independence. Judicial Independence in the Age of Democracy, Virginia: University of Virginia Press, 2001, p. 7 s. Em geral, em âmbito internacional: CAIANIELLO, Michele. L'esercizio dell'azione penale nella Corte penale internazionale, Rivista di diritto processuale, 2001, n. 1, p. $200 \mathrm{~s}$.
} 
Revista Eletrônica de Direito Processual - REDP.

Rio de Janeiro. Ano 11. Volume 18. Número 1. Janeiro a Abril de 2017

Periódico Quadrimestral da Pós-Graduação Stricto Sensu em Direito Processual da UERJ

Patrono: José Carlos Barbosa Moreira. ISSN 1982-7636. pp. 118-149

www.redp.uerj.br

combinações, todavia, são enquadradas em backgrounds histórico-políticos muito distantes do italiano ${ }^{6}$.

De fato, a introdução e a manutenção do art. 112 no texto constitucional italiano reconduz-se a dois fatores fundamentais: em primeiro lugar, o artigo 112 nasce da vontade de se afastar de um passado autoritário (aquele fascista) onde a sujeição do ministério público ao ministro da justiça de fato nulificava a concreta aplicabilidade do homólogo princípio, embora até então formalmente expresso. Como frequentemente ocorre, decidiu-se por uma solução de compromisso: por um lado assegurou-se a máxima independência ao parquet, e, por outro lado, tentou-se ponderar tal independência com a previsão do princípio de obrigatoriedade da ação penal. Diferentemente, a razão pela qual o princípio de obrigatoriedade da ação penal continua a operar até hoje é reconduzível às relações entre a magistratura e a política que, diante dos acontecimentos dos anos noventa, está continuamente e progressivamente em crise: em tal contexto, parece quase impraticável imaginar uma reforma compartilhada que altere totalmente a ordem atual eliminando a obrigatoriedade da ação penal e, assim, subordine o Ministério Público ao poder executivo ${ }^{7}$.

Todavia, embora tenha sem dúvidas constituído uma das conquistas mais importantes da Carta fundamental italiana, porque marcou a superação de uma concepção potestativa da justiça $^{8}$, o art. 112 hoje é objeto de uma tal inefetividade concreta que conduz a perguntarse sobre a possibilidade de mantê-lo, atenuando, porém, a sua rigidez, ou então, de abandonálo definitivamente, optando-se por espaços de oportunidade, ${ }^{9}$ ainda que controlados. Manter inalterada a situação atual significa, de fato, somente fechar os olhos diante dos paradoxos que parecem incompatíveis com a fisionomia de um Estado com forte tradição democrática, como o italiano.

\footnotetext{
${ }^{6}$ Em termos mais amplos: CALAMANDREI, Piero. Relazione preliminare sul tema «Posizione costituzionale del potere giudiziario nella nuova Costituzione italiana». In: D’ALESSIO, Gianfranco (org.), Alle origini della Costituzione italiana. I lavori preparatori della Commissione per studi attinenti alla riorganizzazione dello Stato. 1945-1946, Bologna: il Mulino, 1979, p. 623.

${ }^{7}$ Em perspectiva comparada, ver: LUPARIA, Luca. Obbligatorietà e discrezionalità dell'azione penale nel quadro comparativo europeo, Giurisprudenza italiana, 2002, p. 8 s.

${ }^{8}$ Sobre isso, ver: KOSTORIS, Roberto E. Per un'obbligatorietà temperata dell'azione penale. Rivista di diritto processuale, 2007, p. $875 \mathrm{~s}$.

9 "Numa concepção mais estrita, está-se frente a um sistema que admite a oportunidade quando é lícito ao Ministério Público não perseguir todos os fatos delitivos que lhe são submetidos, ou quando pode configurálos prescindindo de circunstâncias fáticas relevantes, do prisma jurídico-penal, segundo as normas objetivas, ou quando lhe é permitido não se ater à legalidade para valorar juridicamente esses fatos." (GIACOMOLLI, Nereu José. Legalidade, Oportunidade e Consenso no Processo Penal na Perspectiva das Garantias Constitucionais. Porto Alegre: Livraria do Advogado, 2006. p. 68).
} 
Revista Eletrônica de Direito Processual - REDP.

Rio de Janeiro. Ano 11. Volume 18. Número 1. Janeiro a Abril de 2017

Periódico Quadrimestral da Pós-Graduação Stricto Sensu em Direito Processual da UERJ

Patrono: José Carlos Barbosa Moreira. ISSN 1982-7636. pp. 118-149

www.redp.uerj.br

O primeiro destes paradoxos é a absoluta irrealizabilidade prática do princípio. $\mathrm{O}$ art.

112 apresenta uma "solução formalmente perfeita" independência e a obrigatoriedade da ação penal como faces da mesma moeda e as consideraram a melhor expressão constitucional da igualdade de todos os cidadãos. Todavia, ditas aspirações não encontraram resposta nos fatos. É frequente dizer que o problema do legislador italiano é se inspirar sempre na perfeição. Em outras palavras, diz-se que os constituintes deram vida a um sistema formalmente perfeito, mas humanamente irrealizável na prática, e, assim, abrindo caminho a possíveis distorções.

Dita constatação não é somente uma conjetura, mas uma consciência oficial. De fato, a Comissão de reforma do ordenamento judiciário nomeada pelo Ministro Giovanni Conso ${ }^{11}$ declarou a objetiva impossibilidade de perseguir todos os crimes, até mesmo por meio uma hipotética ampla operação de despenalização. Enfim, a Comissão afirmou a necessidade de estabelecer um sistema de prioridade no exercício da ação penal ${ }^{12}$. Além disto, as conclusões da Comissão de reforma são corroboradas pelo fato de que, diante da impossibilidade prática de perseguir todos os crimes, cada singular acusador é de fato obrigado a aplicar critérios individuais e discricionários para dar prioridade a determinados processos ao invés de outros.

Paradoxalmente, o princípio de obrigatoriedade da ação penal, concebido como expressão do princípio de igualdade, uma vez aplicado corre o risco de determinar desigualdades de disciplina entre os cidadãos. Assim interpretado, parece-se impedir uma regulamentação a nível central dos critérios de prioridade, deixando que cada procurador estabeleça discricionariamente os próprios critérios. Desta forma, o atual regime determina a substancial subtração ao controle democrático de verdadeiras escolhas de política criminal tanto em nível nacional como internacional.

Tal descrição do panorama italiano reproduz essencialmente o cenário brasileiro em relação à temática. Embora a Constituição brasileira não preveja expressamente a

\footnotetext{
${ }^{10}$ Assim: Atti Parlamentari, XVI Legislatura, Senato della Repubblica, Desenho de lei que contem "delega al governo in materia di determinazione dei criteri di priorità nell'esercizio dell'azione penale" assinado por Cossiga, comunicado à Presidência em 29 de abril de 2008, impresso n. 210, 4. Disponível em: <www.senato.it>. Acesso em: 4 mar. 2017.

11 Nomeada com decreto ministerial de 8 de fevereiro de 1993. Ver também: MARZADURI, Enrico. Considerazioni sui profili di rilevanza processuale del principio di obbligatorietà dell'azione penale a vent'anni dalla riforma del codice di procedura penale. In: PACE, Alessandro; BARTOLE, Sergio; ROMBOLI, Roberto (org.), Problemi attuali della giustizia in Italia, Napoli: Jovene, 2010, 124 s.

${ }^{12}$ Ver: Atti Parlamentari, XVI Legislatura, Senato della Repubblica, Desenho de lei que "delega al governo in materia di determinazione dei criteri di priorità nell'esercizio dell'azione penale”, cit. p. 3 s.
} 
Revista Eletrônica de Direito Processual - REDP.

Rio de Janeiro. Ano 11. Volume 18. Número 1. Janeiro a Abril de 2017

Periódico Quadrimestral da Pós-Graduação Stricto Sensu em Direito Processual da UERJ

Patrono: José Carlos Barbosa Moreira. ISSN 1982-7636. pp. 118-149

www.redp.uerj.br

obrigatoriedade da ação penal, a doutrina majoritariamente afirma a sua caracterização no ordenamento processual penal pátrio, ${ }^{13}$ invocando, inclusive, o dispositivo italiano como exemplo paradigmático. ${ }^{14}$ Conforme Scarance Fernandes, embora não consagrada constitucionalmente, a obrigatoriedade foi adotada pelo Código de Processo Penal de 1941, ao passo que seus artigos 42 e 576 atestam que, formulada a acusação ou interposto o recurso, o promotor não pode desistir do processo. ${ }^{15}$

Ainda que a crise descrita há muito pelos autores italianos também se coloque no Brasil, diante da inviabilidade prática do processamento de todas as notícias-crimes pela Justiça Criminal, a doutrina nacional ainda carece de maiores estudos sobre a possibilidade de introdução de critérios de não-obrigatoriedade e de sua operacionalização concreta no sistema pátrio. De qualquer modo, é inegável que existem vozes apontando a necessidade de questionamento ao caráter absoluto da obrigatoriedade: segundo Jacinto Coutinho, “é preciso considerar que tal princípio da obrigatoriedade, ainda que fosse possível pensar estar atrelado ao princípio da legalidade, deve ser relativizado [...]”. ${ }^{16}$ Além disso, medidas concretas nesse sentido têm sido adotadas pelo Ministério Público Federal, por exemplo, as orientações 26 e 30 da $2^{a}$ Câmara de Coordenação e Revisão, que regulam a "promoção de

\footnotetext{
${ }^{13}$ Nesse sentido: SILVA, Eduardo Araujo da. Ação Penal Pública: princípio da oportunidade regrada. $2^{\mathrm{a}}$ ed. São Paulo: Atlas, 2000. p. 32; JARDIM, Afrânio Silva. Ação penal pública: princípio da obrigatoriedade. $3^{\mathrm{a}}$ ed. Rio de Janeiro: Forense, 1998. p. 92-99. Em tom crítico, Wanderley Gazoto aponta que "de forma geral, pode-se dizer que a doutrina jurídica brasileira, de maneira formalista e acrítica, atribui ao princípio da obrigatoriedade da ação penal pública sentido absolutamente inflexível, concebendo o membro do Ministério Público como um autômato formalizador de denúncias" (GAZOTO, Luís Wanderley. O Princípio da NãoObrigatoriedade da Ação Penal Pública. Uma crítica ao formalismo no Ministério Público. Barueri: Manole, 2003. p. 90). Em sentido contrário à obrigatoriedade no processo penal brasileiro, ver: SILVA, Edimar Carmo da; URANI, Marcelo Fernandez. Manual de Direito Processual Penal Acusatório. Doutrina e Jurisprudência. Curitiba: Juruá, 2013. p. 94-97. Descrevendo a posição majoritária da doutrina brasileira no sentido da adoção da obrigatoriedade: PRADO, Geraldo. Prova penal e sistema de controles epistêmicos. A quebra da cadeia de custódia das provas obtidas por métodos ocultos. São Paulo: Marcial Pons, 2014. p. 22.

${ }^{14}$ Conforme Jacinto Coutinho, "este princípio diz com a obrigatoriedade do exercício da ação penal pública, para evitar-se qualquer manipulação por parte do órgão acusador e, por outra parte, eventuais pressões que possa sofrer. Assim, entende-se que, presentes as condições da ação, deve exercitá-la, ainda que não exista previsão expressa na lei (como fez o legislador constituinte italiano, ao inserir o art. 112, na CR, que expressa: 'Il pubblico ministero ha l'obbligo di esercitare l'azione penale'), embora seja certo ser uma decorrência do princípio constitucional da isonomia" (COUTINHO, Jacinto Miranda. Introdução aos princípios gerais do direito processual penal brasileiro. Revista de Estudos Criminais, São Paulo, n. 01, p. 26-51, 2001. p. 41).

${ }^{15}$ FERNANDES, Antonio Scarance. Teoria Geral do Procedimento e O Procedimento no Processo Penal. São Paulo: RT, 2005. p. 263.

${ }^{16}$ COUTINHO, Jacinto Miranda. Introdução aos princípios gerais do direito processual penal brasileiro. Revista de Estudos Criminais, São Paulo, n. 01, p. 26-51, 2001. p. 42.
} 
Revista Eletrônica de Direito Processual - REDP.

Rio de Janeiro. Ano 11. Volume 18. Número 1. Janeiro a Abril de 2017

Periódico Quadrimestral da Pós-Graduação Stricto Sensu em Direito Processual da UERJ

Patrono: José Carlos Barbosa Moreira. ISSN 1982-7636. pp. 118-149

www.redp.uerj.br

arquivamento" e os "critérios a serem observados nas promoções de arquivamento referentes aos crimes não considerados prioritários pela $2^{\mathrm{a}} \mathrm{CCR}$ ". ${ }^{17}$

Diante de tais problematizações, este artigo pretende analisar o cenário italiano e as principais discussões relacionadas à obrigatoriedade da ação penal e à possibilidade de previsão de critérios de priorização para relativização de tal premissa. Trata-se de questão primordial diante da generalizada sobrecarga da justiça criminal, especialmente em razão do expressivo e há muito descrito fenômeno da expansão do direito penal. Assim, coloca-se o seguinte problema: é sustentável a ideia de uma obrigatoriedade absoluta, que determine um dever de acusação pública em todos os casos de ocorrência de um crime e de existência elementos suficientes para a sua comprovação?

\section{1. $O$ conceito de ação e o controle jurisdicional sobre o dever de agir}

Claramente expresso no art. 50, inciso $1^{\circ}, \mathrm{CPP}$ italiano ${ }^{18}$, (“o ministério publico exercita a ação penal quando não subsistam os pressupostos para o pedido de arquivamento"); o conceito retorna também no art. 405, inciso $1^{\circ}$, CPP italiano ("o ministério público, quando não tem que pedir o arquivamento, exercita a ação penal formulando a imputação, nos casos previstos nos títulos II, III, IV do livro VI ou então com o pedido de submissão a julgamento"); no art. 412, inciso $1^{\circ}$, CPP italiano ("o procurador geral diante a corte d'appello dispõe com decreto motivado a avocação do inquérito se o ministério público não exercita a ação penal ou não requer o arquivamento entre o tempo

\footnotetext{
${ }^{17}$ Disponíveis em: <http://www.mpf.mp.br/atuacao-tematica/ccr2/orientacoes/documentos/orientacao-no-26> e <http://www.mpf.mp.br/atuacao-tematica/ccr2/orientacoes/documentos/orientacao-no-30>. Acesso em: 10 mar. 2017.

${ }^{18}$ Em referência histórica, ver: CALAMANDREI, Piero. La relatività del concetto di azione, Rivista di diritto processuale civile, 1939, I, p. 22; CARRARA, Francesco. Azione penale, Rivista penale, II (1875), vol. III (I s.), p. 18; CARRARA, Francesco. Progresso e regresso del giure penale nel nuovo Regno d'Italia osservato nella dottrina, nella legislazione e nella giurisprudenza. In: CARRARA, Francesco, Opuscoli di diritto criminale, vol. IV, Lucca: Tipografia Giusti, 1874, p. 44 s. Ver também: CHIAVARIO, Mario. Appunti sulla problematica dell'“azione" nel processo penale italiano: incertezze, prospettive, limiti. Rivista trimestrale di diritto e procedura civile, 1975, p. 905 s. e ROCCO, Alfredo. Sulla delega al Governo del Re della facoltà di emendare il Codice penale, il Codice di procedura penale, le leggi sull'Ordinamento giudiziario e di apportare nuove modificazioni e aggiunte al Codice Civile. Discorso pronunciato alla Camera dei Deputati nella tornata del 27 maggio 1925, Roma, Tip. della Camera dei Deputati 1925, p. 29-30. O texto consta também em: ROCCO, Alfredo. Discorsi parlamentari, com artigo de VASSALLI, Giuliano, Bologna: il Mulino, 2005, p. 192-3.
} 
Revista Eletrônica de Direito Processual - REDP.

Rio de Janeiro. Ano 11. Volume 18. Número 1. Janeiro a Abril de 2017

Periódico Quadrimestral da Pós-Graduação Stricto Sensu em Direito Processual da UERJ

Patrono: José Carlos Barbosa Moreira. ISSN 1982-7636. pp. 118-149

www.redp.uerj.br

estabelecido pela lei”). Por meio destas normas, o legislador de 1988 estabeleceu pelo menos três princípios fundamentais em matéria de ação penal e arquivamento.

O primeiro determina que o pedido de arquivamento e exercício da ação penal representam duas escolhas alternativas do órgão da acusação, fundamentados sobre pressupostos particulares ${ }^{19}$. O pedido de arquivamento pode-se definir, portanto, como o ato com o qual o ministério público - considerando que faltem as condições - manifesta a vontade de não exercitar a ação penal em relação a uma determinada notícia de crime ${ }^{20}$. Esta escolha do legislador italiano de 1988 reflete uma precisa concepção do princípio de obrigatoriedade da ação penal estabelecido no art. 112 Const. italiana. Em linha com a interpretação já prevalente na doutrina na vigência do código revogado, considerou-se compatível com a norma constitucional um sistema que vincule o ministério público a exercer a ação penal não em consequência da mera recepção da notícia de crime, mas somente quando recorram ulteriores pressupostos estabelecidos pela lei e ligados - pelo menos tendencialmente - a uma avaliação de "validade" da mesma notícia ${ }^{21}$. Todavia, para Francesco Caprioli não é claro se o legislador - configurando a ação e o arquivamento como realidade particular quanto aos respectivos pressupostos - tenha predisposto um "sistema no qual a verificação ou não de tais pressupostos determine também duas simétricas situações

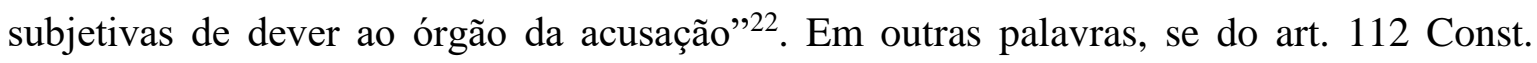
italiana se interpreta claramente que o Ministério Público tem o dever de agir quando se realizam as condições previstas pela lei para o exercício da ação penal, não é pacifico da mesma forma que, no caso oposto, "a apresentação do pedido de arquivamento e possa considerar como um ato igualmente 'devido' pelo representante da acusação"23.

\footnotetext{
${ }^{19}$ CAPRIOLI, Francesco. L'archiviazione, Napoli: Jovene, 1994, p. 328 s. Ver também: CAIANIELLO, Michele. Archiviazione (dir. proc. pen.), Enc. Dir., Annali, II, t. 1, Milano: Giuffrè, 2008, 64 s.

${ }^{20}$ Essas visões são compartilhadas por quase a totalidade da doutrina. Vejam-se: NOBILI, Massimo. La nuova procedura penale. Lezioni agli studenti, Bologna: Clueb, 1989, p. 71 e 89; GIOSTRA, Glauco. L'archiviazione. Lineamenti Sistematici e questioni interpretative, Torino: Giappichelli, 1994, p. 12 e GREVI, Vittorio. Archiviazione per "inidoneità probatoria" ed obbligatorietà dell'azione penale, Rivista italiana di diritto $e$ procedura penale, 1990, p. 1280.

${ }^{21}$ GIOSTRA, Glauco. L'archiviazione, cit., p. 8; GIULIANI, Livia. La regola di giudizio in materia di archiviazione (art. 125 disp. att. c.p.p.). Cassazione penale, 1992, p. 250 e GREVI, Vittorio. Archiviazione, cit., p. 1281 e 1297. Ver também: DI CHIARA, Giuseppe. Il pubblico ministero e l'esercizio dell'azione penale. In: FIANDACA, Giovanni; DI CHIARA, Giuseppe. Una introduzione al sistema penale, Napoli, 2003, p. 235 e s.

${ }^{22}$ CAPRIOLI, Francesco. L'archiviazione, cit., p. 331.

${ }^{23}$ CAPRIOLI, Francesco. L'archiviazione, cit., p. 332.
} 
Revista Eletrônica de Direito Processual - REDP.

Rio de Janeiro. Ano 11. Volume 18. Número 1. Janeiro a Abril de 2017

Periódico Quadrimestral da Pós-Graduação Stricto Sensu em Direito Processual da UERJ

Patrono: José Carlos Barbosa Moreira. ISSN 1982-7636. pp. 118-149

www.redp.uerj.br

Como no passado, a doutrina se posicionou quase unanimemente em favor da solução afirmativa ${ }^{24}$, que se considera a única compatível com o próprio princípio de obrigatoriedade da ação penal e com outras disposições constitucionais ${ }^{25}$. Todavia, o exercício aventado da potestas agendi não faz desencadear nenhum mecanismo sancionatório de natureza processual: se o ministério público dispõe ou requer o envio a julgamento em falta das condições estabelecidas pela lei (por exemplo, diante uma notitia criminis claramente infundada), o ordenamento não reage nem com uma cominatória de invalidade do ato propulsivo (em hipótese, pela violação das normas inerentes à "iniciativa do ministério público no exercício da ação penal”), nem obrigando o juiz a pronunciar uma decisão que ateste a ilegitimidade de tal iniciativa (como ocorre, no caso de falta de uma condição de procedibilidade, por meio da fórmula mais do que nunca significativa da ação penal que "não deveria ser iniciada"), nem, enfim - considerado o princípio de irretratabilidade da ação penal reafirmado pelo art. 50, inciso $3^{\circ} \mathrm{CPP}$ italiano -, consentindo ao juiz "transformar" a ação em inação mediante o pronunciamento de um ato de arquivamento não solicitado, segundo esquemas análogos àqueles previstos para a audiência preliminar na lei de delegação de $1974^{26}$.

Embora exerça a ação em condições que legitimariam o pedido de arquivamento, a ação penal acarreta, portanto, inteiramente a sua eficácia típica, determinando o início do processo e a pronúncia de uma decisão jurisdicional sobre a imputação ${ }^{27}$. De consequência, um “dever" do ministério publico de não agir (e de pedir o arquivamento) pode se considerar positivamente subsistente no sistema processual penal italiano somente no caso de este se configurar como um dever cuja violação é improdutiva dos efeitos jurídicos, deduzindo-se a sua existência somente de uma previsão do modelo legal de comportamento ${ }^{28}$.

\footnotetext{
${ }^{24}$ Assim, por exemplo, GIOSTRA, Glauco. L'archiviazione, cit., p. 11 s. e GREVI, Vittorio. Archiviazione, cit., $1281 \mathrm{~s}$.

${ }^{25}$ Ver: RIVELLO, Pier P. Un intervento della Corte Costituzionale sul delicato problema dell'archiviazione per l'inidoneità degli elementi acquisiti nelle indagini preliminari a sostenere l'accusa in giudizio, em La difesa penale, 1991, p. $62 \mathrm{~s}$.

${ }^{26}$ Na jurisprudência, ver: Cassazione penal, 9 de março de 1993, em Massimario cassazione penale, 1993, 6, p. 129.

${ }^{27}$ Isto vale até mesmo na hipótese em que venha emanada uma sentença de "non luogo a procedere", embora tal sentença tenha os efeitos negativos que podem derivar de uma ação penal exercida de modo pretencioso. ${ }^{28}$ Ver: CORDERO, Franco. Le situazioni soggettive nel processo penale, Torino: Giappichelli, 1957, p. 108 e 116 s.: "cada comportamento que não colime com aquele respeito ao qual a norma [...] fornece a descrição, por isso mesmo pode ser qualificado como não devido, sem que na avaliação entre algum critério fora daquele representado pela previsão da fattispecie real àquela abstrata" (tradução livre).
} 
Revista Eletrônica de Direito Processual - REDP.

Rio de Janeiro. Ano 11. Volume 18. Número 1. Janeiro a Abril de 2017

Periódico Quadrimestral da Pós-Graduação Stricto Sensu em Direito Processual da UERJ

Patrono: José Carlos Barbosa Moreira. ISSN 1982-7636. pp. 118-149

www.redp.uerj.br

O segundo princípio que resulta definitivamente consagrado na nova disciplina da ação penal regula que o seu exercício coincide com a emanação do ato de formulação da imputação (art. 405 , inciso $1^{\circ}$ ). Aqui o compromisso vinculante do legislador tipifica os atos de imputação: pedido de reenvio a julgamento, ato de imputação introdutivo de um rito especial diferente do juízo abreviado (art. 60 e 405 CPP italiano). O modelo de ação penal que que desta forma vem proposto é marcadamente inspirado nos cânones civilísticos da ação como "pedido" (ou seja, como um ato que postula uma necessária "tomada de contato" entre quem age em julgamento e o órgão julgador" ${ }^{29}$; contrariamente, o arquivamento vem inteiramente relegado na fase que se pode definir "pre-imputativa" 30 do caso procedimental.

Contrapondo a ação penal ao arquivamento e fazendo coincidir o seu exercício com a emissão do ato de imputação, o legislador italiano de 1988, todavia, não fez outra coisa a não ser reafirmar escolhas sistemáticas já claramente expressas pelo projeto preliminar de $1978^{31}$ e deduzíveis em via interpretativa pela mesma disciplina do código revogado. Seja em relação ao código de 1930 como ao projeto de 1978, a verdadeira novidade é representada pela circunstância que o ato de exercício da ação penal coincide integralmente - no procedimento ordinário - com o ato por meio do qual o ministério público pede ou dispõe o reenvio a julgamento ${ }^{32}$. É este o terceiro princípio cardinal sobre o qual se baseia a disciplina das relações entre ação penal e arquivamento: o código o expressa claramente no art. 405 (“o ministério publico, exercita a ação penal, formulando a imputação [...] com o pedido de reenvio a julgamento").

Embora em um contexto normativo profundamente diversificado, o procedimento de arquivamento da notícia de crime descrita no CPP italiano conserva a sua função de assegurar o controle "jurisdicional" - isto é, um controle devolvido a um órgão da jurisdição $^{33}$ - sobre a decisão do ministério público de não exercer a ação penal.

Fruto de uma escolha do legislador delegante feita não sem algumas hesitações e com a plena consciência de sua excentricidade em relação às premissas tradicionais do "processo

\footnotetext{
${ }^{29}$ Nesta direção: CAPRIOLI, Francesco. L'archiviazione, cit., p. 335. Ver também: BORRACCETTI, Vittorio. Archiviazione, indagini preliminari e obbligatorietà dell'azione penale. Questione giustizia, 1989, p. 572 e CHIAVARIO, Mario. L'obbligatorietà dell'azione penale: il principio e la realtà. Cassazione penale, 1993, p. 2662.

${ }^{30}$ Assim: CAPRIOLI, Francesco. L'archiviazione, cit., p. 335.

${ }^{31}$ Por outro lado, o art. 50 CPP italiano vigente é a exata reprodução do art. 57 daquele projeto.

32 GIOSTRA, Glauco. L'archiviazione, cit., p. 13 s. e GREVI, Vittorio. Archiviazione per "inidoneità probatoria", cit., p. 1276 e 1288.

${ }^{33}$ CAPRIOLI, Francesco. L'archiviazione, cit., p. 511 s.
} 
Revista Eletrônica de Direito Processual - REDP.

Rio de Janeiro. Ano 11. Volume 18. Número 1. Janeiro a Abril de 2017

Periódico Quadrimestral da Pós-Graduação Stricto Sensu em Direito Processual da UERJ

Patrono: José Carlos Barbosa Moreira. ISSN 1982-7636. pp. 118-149

www.redp.uerj.br

de partes", a reconfirmação do sistema jurisdicional de controle sobre o dever de agir provocou na doutrina italiana reações muito contrastantes. Assim, se, por um lado, a decisão de atribuir ao juiz do inquérito preliminar o poder de sindicar a escolha abdicativa do ministério público foi considerada como "o ponto [...] de mais acentuada desarmonia entre regras acusatórias e arquitetura do novo processo penal”, expressão de uma vontade legislativa incapaz de subtrair à "força evocativa das etiquetes" e à "sugestividade da interferência jurisdicional a qualquer custo" 34 , por outro lado - e em uma perspectiva diametralmente oposta - considerou-se que a adoção do mecanismo de arquivamento "judicial” da notícia de crime constituiu um percurso obrigatório diante do perfil da legitimidade constitucional, considerando-se incompatível com o art. 112 Const. a predisposição de qualquer controle sobre o não exercício da ação da potestas agendi que não fosse aquele entregue ao órgão da jurisdição ${ }^{35}$.

Todavia, para Francesco Caprioli, nenhum destes juízos podem ser integralmente compartilhados ${ }^{36}$.

Quanto ao relevo segundo o qual o envolvimento do juiz na fase do início do iter processual determinaria "um evidente afastamento do processo em direção de esquemas inquisitivos" ${ }^{37}$, não se pode deixar de observar como uma tal preocupação seja atualmente atenuada pelo efeito do papel muito menos gravitacional que se atribui ao juiz do arquivamento no desenrolar subsequente do procedimento. Se o inequívoco contra reum manifestado pelo órgão jurisdicional por meio da rejeição do pedido de arquivamento fazia nascer a dúvida de possíveis degradações inquisitivas em um regime normativo como aquele precedente ao de 1989, é inegável que dúvidas do mesmo tipo surgem em medidas mais reduzidas em um sistema como o atual, em que o juiz do inquérito que discorde do pedido de arquivamento não pode fazer nada além de indicar ao órgão da acusação as ulteriores investigações a serem feitas ou convidar este último a exercer imediatamente a ação penal ${ }^{38}$.

\footnotetext{
34 TRANCHINA, Giovanni. Ruoli naturali ed innaturali del giudice nel nuovo processo penale, Indice penale, $1989,621 \mathrm{~s}$.

${ }^{35}$ FERRUA, Paolo. Il ruolo del giudice nel controllo delle indagini e nell'udienza preliminare. In: PISANI, Mario (org.). Studi in memoria di Pietro Nuvolone, III, Il nuovo processo penale. Studi di diritto straniero e comparato, Milano: Giuffrè, 1991, p. 55 s., o qual considera "constitucionalmente devida a presença de um controle jurisdicional".

${ }^{36}$ CAPRIOLI, Francesco. L'archiviazione, cit., p. $515 \mathrm{~s}$.

${ }^{37}$ A expressão é de: TRANCHINA, Giovanni. Ruoli naturali ed innaturali, cit., p. 621.

${ }^{38}$ Veja-se: CAPRIOLI, Francesco. L'archiviazione, cit., p. 514.
} 
Revista Eletrônica de Direito Processual - REDP.

Rio de Janeiro. Ano 11. Volume 18. Número 1. Janeiro a Abril de 2017

Periódico Quadrimestral da Pós-Graduação Stricto Sensu em Direito Processual da UERJ

Patrono: José Carlos Barbosa Moreira. ISSN 1982-7636. pp. 118-149

www.redp.uerj.br

Com três sucessivas pronunciações, a Corte Constitucional oportunamente declarou

a ilegitimidade constitucional do art. 34 , inciso $2^{\circ}, \mathrm{CPP}$ italiano (por contraste com os artigos 76 e 77 da Constituição), na parte em que admitia que participasse do juízo abreviado e do dibattimentale o juiz do inquérito diante do Tribunal que tivesse emanado, respectivamente a ordinanza ex art. 409 , inciso $5^{\circ}$, CPP italiano ${ }^{39}$.

Em relação à visão segundo a qual a existência de um controle jurisdicional sobre o não exercício da ação penal seria "constitucionalmente devida", deve-se, por outro lado, ressaltar algumas considerações sobre o conteúdo da regra constitucional e a taxa de "efetividade" que tem que ser-lhe garantida.

O que se pode afirmar com certeza a partir do art. 112 Const. é que seria constitucionalmente ilegítima uma disciplina processual que não previsse alguma real forma de controle sobre o não exercício da ação por parte de cada representante do ministério público, ou então entregasse a supervisão de suas escolhas, como acontecia em época fascista, a um órgão hierarquicamente superior. No primeiro caso, de fato, a obrigação de agir imposta ao acusador se reduziria a uma recomendação vazia do princípio; no segundo caso, o controle sobre a observância da obrigação seria atribuído a um órgão interno que, podendo inibir ab origine as iniciativas processuais do órgão precedente, terminaria por se transformar no autêntico dominus da ação e da inação penal ${ }^{40}$. Segundo Francesco Caprioli, superados esses requisitos mínimos de tolerabilidade, todavia, se passa à esfera do constitucionalmente necessário àquela do constitucionalmente preferível: os diferentes sistemas de controle que podem ser predispostos pelo legislador ordinário se deixam apreciar em termos de maior ou menor eficácia, porém não mais em termos de conformidade ou deformidade em relação ao art. 112 Const. Se isto é verdadeiro, a própria atribuição exclusiva do poder de controle das procuradorias gerais é uma solução que hoje talvez poderia se considerar não lesiva do preceito constitucional.

\footnotetext{
39 Trata-se de Corte const. 15 de outubro de 1990, n. 496, Corte const., 4 de novembro de 1991, n. 401 e Corte const. 19 de dezembro de 1991, n. 502, disponíveis em: <http://www.giurcost.it>. Acesso em: 4 mar. 2017. Remete-se para informações mais detalhadas a: CAPRIOLI, Francesco. L’archiviazione, cit., p. 516 s.

${ }^{40}$ Sobre o exercício da ação por parte de privados, veja-se: CAPRIOLI, Francesco. L'azione penale privata e la tutela della persona offesa. In: ZAPPALÀ, Vincenzo (org.), Azione civile e prescrizione processuale nella bozza di riforma della Commissione Riccio, Torino: Giappichelli, 2010, p. 26 s.; CAPRIOLI, Francesco. Il processo penale dopo la legge Carotti, Commento agli artt. 25-26, em Diritto penale e processo, 2000, p. 291 s. e CAIANIELLO, Michele. Poteri dei privati nell'esercizio dell'azione penale, Torino: Giappichelli, 2003.
} 
Revista Eletrônica de Direito Processual - REDP.

Rio de Janeiro. Ano 11. Volume 18. Número 1. Janeiro a Abril de 2017

Periódico Quadrimestral da Pós-Graduação Stricto Sensu em Direito Processual da UERJ

Patrono: José Carlos Barbosa Moreira. ISSN 1982-7636. pp. 118-149

www.redp.uerj.br

Por outro lado, o sistema jurisdicional de controle sobre o não exercício da ação penal não deve nem sequer ser sopesado em relação à sua concreta eficácia. Aos seus tradicionais limites operativos, se adicionam aqueles derivantes do novo regime da fase que precede o dibattimento, e, em particular, da impossibilidade para o juiz do inquérito de se substituir diretamente ao órgão da acusação na condução da fase investigativa e no exercício da ação penal. Seja na hipótese em que o ministério público não manifeste alguma vontade de proceder ou não proceder, seja na hipótese em que a intervenção do juiz do arquivamento se releve ineficaz, a única possibilidade de garantir o respeito efetivo do art. 112 Const. é aquele que passa por meio do exercício do poder de avocação do procurador geral. Não é um caso que a mesma doutrina que considera "constitucionalizado" o mecanismo de controle termina com admitir que o único modo para "devolver ao sistema [...] seguras credenciais de legitimidade constitucional" é aquele de considerar obrigatória a intervenção avocativa do procurador geral não somente na hipótese em que a inércia do representante do ministério público se procrastine além dos prazos de lei (art. 412, inciso $1^{\circ}, \mathrm{CPP}$ italiano), mas também no caso de inobservância das ordens apresentadas pelo juiz ao ministério público conforme os artigos 409 e 415 CPP italiano que disciplinam o procedimento de arquivamento no ordenamento italiano ${ }^{41}$.

Mas concentrando a atenção sobre o problema dos mecanismos de verificação das escolhas do ministério público, corre-se o risco, todavia, de negligenciar o aspecto não menos essencial do objeto do controle definido sobre a regra de juízo que o legislador ordinário, integrando o princípio constitucional de obrigatoriedade, determina em relação ao fundamento da decisão do agir ou não agir.

Como é notório, o art. 112 Const. impõe que os pressupostos de operatividade do dever de exercer a ação penal sejam indicados pelo legislador de modo taxativo, eliminando assim, pelo menos tendencialmente, qualquer margem de discricionariedade valorativa no accertamento de sua existência ${ }^{42}$. Obrigar o ministério público a dar inicio ao processo em presença de condições normativas com conteúdo indeterminado, significa, simplesmente, transferir a discricionariedade para um terreno diferente: vinculada a decisão de agir diante dos pressupostos de lei, permite-se que as avaliações discricionárias do órgão da acusação

\footnotetext{
${ }^{41}$ Assim CAPRIOLI, Francesco. L'archiviazione, cit., p. 522 e 573 s. Ver também: GIOSTRA, Glauco. L'archiviazione, cit., p. $75 \mathrm{~s}$.

${ }^{42}$ Para uma rigorosa afirmação do princípio, ver: CAPRIOLI, Francesco. L'archiviazione, cit., p. 522 s.
} 
Revista Eletrônica de Direito Processual - REDP.

Rio de Janeiro. Ano 11. Volume 18. Número 1. Janeiro a Abril de 2017

Periódico Quadrimestral da Pós-Graduação Stricto Sensu em Direito Processual da UERJ

Patrono: José Carlos Barbosa Moreira. ISSN 1982-7636. pp. 118-149

www.redp.uerj.br

governem a verificação da existência dos mesmos pressupostos, com substancial elisão do preceito constitucional ${ }^{43}$. Em um tal contexto, até mesmo o controle jurisdicional perde qualquer função de tutela do princípio de obrigatoriedade, enquanto a verificação operada pelo juiz “degrad[a] a supina aceitação das opções do ministério publico ou a sobreposição de um arbítrio a um outro: perspectivas, ambas, constitucionalmente inaceitáveis" ${ }^{\prime 4}$.

Por este ponto de vista, a vigente disciplina de arquivamento não parece subtrair-se à censura de ilegitimidade constitucional. Impermeada sobre a regra de "inidoneidade dos elementos recolhidos no curso do inquérito preliminar a sustentar a acusação em juízo", a fattispecie processual dos artigos 408 e 125 das disposições que dão atuação ao CPP italiano certamente não satisfazem os requisitos de taxatividade e determinação que são indispensáveis conforme o art. 112 Const. $^{45}$

Em relação ao artigo 125 das disposições de atuação do CPP italiano, a Corte Constitucional afirmou que o não fundamento ex art. 408 equivalha à "manifesto não fundamento" prevista pela lei delegada, e que o arquivamento pode ser pedido somente quando, tendo o MP feito todas as investigações possíveis (completude do inquérito), o julgamento seja inútil. Enfim, é o caso de reafirmar que a função de controle do mecanismo de arquivamento corre o risco de ser ulteriormente redimensionada pelo efeito da tendência jurisprudencial a dilatar demasiadamente os espaços de legitima rejeição das informativas de crime.

Se a função do procedimento descrito nos arts. 408-415 s. CPP italiano é aquela de impedir ao ministério público de subtrair-se ilegitimamente à obrigação de exercitar a ação penal, pode-se bem dizer que as hipóteses de rejeição do pedido de arquivamento apartem a fisiologia do instituto ao invés de que a sua patologia, sendo nessas circunstâncias que o mecanismo de controle jurisdicional demonstra a sua real eficácia.

Enfim, uma particular forma de rejeição do arquivamento é prevista pelo art. 415, inciso $2^{\circ}, \mathrm{CPP}$ italiano para a hipótese na qual tal pedido seja apresentado como o êxito de um inquérito contra sujeitos não identificados. Neste caso, de fato, o juiz do inquérito, "se

\footnotetext{
${ }^{43}$ GIOSTRA, Glauco. L'archiviazione, cit., p. 11.

${ }^{44}$ GIOSTRA, Glauco. L'archiviazione, cit., p. 11 (tradução livre). Ver também: MANZIANI, Domanico. Il principio di obbligatorietà dell'azione penale oggi: confini e prospettive, em Criminalia, 2010, p. 332 s.; MARZADURI, Enrico. Il principio di obbligatorietà dell'azione penale oggi: confini e prospettive, Criminalia, 2010, p. 337 s. e RUGGIERI, Francesca. Il principio di obbligatorietà dell'azione penale oggi: confini e prospettive, Criminalia, 2010, p. 301 s.

${ }^{45}$ CAPRIOLI, Francesco. L'archiviazione, cit., p. 524.
} 
Revista Eletrônica de Direito Processual - REDP.

Rio de Janeiro. Ano 11. Volume 18. Número 1. Janeiro a Abril de 2017

Periódico Quadrimestral da Pós-Graduação Stricto Sensu em Direito Processual da UERJ

Patrono: José Carlos Barbosa Moreira. ISSN 1982-7636. pp. 118-149

www.redp.uerj.br

considera que o crime seja atribuível a uma pessoa já individuada, ordena que o nome desta seja inscrito no registro das notícias de delitos"46.

\section{Investigações do acusador para a verificação da notícia de crime}

"Pode o ministério público realizar investigações voltadas à verificação da notícia de um crime?" ${ }^{47}$. Muito discutida durante a vigência do código revogado ${ }^{48}$, a questão hoje parece ser indiscutivelmente resolvida em sentido positivo pelos art. 330 , inciso $1^{\circ}$, e 335 , inciso $1^{\circ}, \mathrm{CPP}$, que fazem expressa referência a notícias de crime "adquiridas por própria iniciativa" pelo acusador. Segundo a visão de muitos, a vontade legislativa de envolver o ministério público na atividade de formação da notitia criminis seria confirmada, de fato, pelos institutos processuais que demonstrariam o quanto é nebuloso o limite entre inquéritos precedente e sucessivos ao conhecimento da notícia de crime: entrevista investigativa, interceptações preventivas, operações sobre cobertura tornariam obsoleta a figura do ministério público como mero receptor de informativas de crime confeccionadas pela polícia $^{49}$.

Convém, todavia, marcar que não se trata de uma visão pacifica. As Corte de Cassação e Constitucional parecem pensar diferentemente ${ }^{50}$ e até mesmo na doutrina não

\footnotetext{
46 Assim o texto da norma (tradução livre). Sobre a ordinanza que dispõem o completamento de ulteriores inquéritos ex art. 409, inciso $4^{\circ}$, CPP italiano e aquela que dispõem a formulação da imputação ex art. 409, inciso $5^{\circ} \mathrm{CPP}$ italiano; os possíveis remédios contra a inobservância destas ordens, ver: CAPRIOLI, Francesco. L'archiviazione, cit., p. 545-584.

${ }^{47}$ CAPRIOLI, Francesco. La ricerca della notizia di reato da parte dell'accusatore, Criminalia, 2011, p. 439 s. (tradução livre). Ver também: GREVI, Vittorio. Ruolo del pm, polizia giudiziaria e rischi di interferenze politiche, Corriere della sera, 16 de julho de 2009 e INSOLERA, Gaetano. La ricerca della notizia di reato da parte dell'accusatore, Criminalia, 2011, p. 452 s.

48 Para um aprofundado debate a três vozes, com êxitos não unívocos: FERRUA, Paolo. L'iniziativa del pubblico ministero nella ricerca della notitia criminis; NOBILI, Massimo. Il magistrato in funzione di polizia tributaria: una ulteriore "supplenza" conforme alle norme vigenti?, e TRANCHINA, Giovanni. Il pubblico ministero "ricercatore" di notizie di reato: una figura poco rassicurante per il nostro sistema. Legislazione penale, 1986 , p. $313 \mathrm{~s}$.

${ }^{49}$ Sobre isso, por exemplo: DE LEO, Francesco. Il pubblico ministero tra completezza investigativa e ricerca dei reati. Cassazione penale, 1995, p. 1431 s.; MELILLO, Giovanni. Le operazioni sotto copertura nelle indagini relative a delitti con finalità di terrorismo. In: DI CHIARA, Giuseppe, Il processo penale tra politiche della sicurezza e nuovi garantismi, Torino: Giappichelli, 2002, p. 33 s. Ver também: ZAPPULLA, Angelo. Notizia di reato. Annali Enc. Dir., 2012, vol. IV, p. 890 s.

${ }^{50}$ Ver: Cassazione penal, 26 de janeiro de 1999, em Cassazione penale, 1999, p. 3458; Corte const. numero 511 de 2000; Corte const. numero 97 de 2001.
} 
Revista Eletrônica de Direito Processual - REDP.

Rio de Janeiro. Ano 11. Volume 18. Número 1. Janeiro a Abril de 2017

Periódico Quadrimestral da Pós-Graduação Stricto Sensu em Direito Processual da UERJ

Patrono: José Carlos Barbosa Moreira. ISSN 1982-7636. pp. 118-149

www.redp.uerj.br

faltam vozes discordantes ${ }^{51}$. Segundo Francesco Caprioli ${ }^{52}$, em primeiro lugar, contesta-se a equação "receber notícia de crime por própria iniciativa" = "realizar atividade de busca e/ou formação da notitia criminis" 53 . A distinção contida no art. 330 CPP entre "receber" e "buscar notícia" dos crimes não faria nada a não ser aludir ao diferente comportamento psicológico do procurador em relação de instrumentos comunicativos qualificados ou não qualificados de transmissão da notícia de crime: a locução "buscar notícia" se limitaria, em outras palavras, a sublinhar "a ausência [no ato formativo] de uma completa predeterminação do objeto, que seria selecionado e isolado dentro de um contexto comunicativo, que não responde à finalidade de fazer em modo que o destinatário perceba a consistência factual" ${ }^{, 5}$. Nem sequer a disciplina das entrevistas investigativas, das interceptações preventivas e das operações sobre cobertura seriam necessariamente interpretadas no sentido de postular um envolvimento direto do ministério público nas dinâmicas de formação da notitia criminis: semelhantes interpretações, afirma-se, caem com a contestada exegese extensiva do art. $330 \mathrm{CPP}^{55}$.

Embasada ou não na previsão normativa ${ }^{56}$, a tese que reconhece ao ministério público a faculdade de iniciar e conduzir investigações finalizadas à formação da notitia criminis deixa sem dúvidas abertas numerosos interrogações. Que tipo de input externo ocorre para que o ministério publico possa ativar a sua atividade de busca? O inquérito à busca da notícia de crime pode nascer de uma pura e simples intuição investigativa do procurador, ou é necessário, como parece ser preferível considerar ${ }^{57}$, pelo menos uma "suspeita" de crime, a

\footnotetext{
${ }^{51}$ Em particular: SANTALUCIA, Giuseppe. Il potere del pubblico ministero di ricerca delle notizie di reato tra principi costituzionali e legge processuale. Rivista italiana di diritto e procedura penale, 2002, $150 \mathrm{~s}$. e VIOLANTE, Luciano. Controllo di legalità. Cassazione penale, 2010, p. 879 s.

${ }^{52}$ CAPRIOLI, Francesco. La ricerca della notizia di reato da parte dell'accusatore. Criminalia, 2011, p. 439 s.

${ }^{53}$ Ver também: GIOSTRA, Glauco. Indagine e prova: dalla non dispersione a nuovi scenari cognitivi. In: GALATI, Antonio (org.), Verso la riscoperta di un modello processuale. Atti del Convegno in memoria di Antonino Galati (Caserta, 12-14 ottobre 2001), Milano: Giuffrè, 2003, p. 47 s. e GIOSTRA, Glauco. Pubblico ministero e polizia giudiziaria, Giustizia Insieme, 2008, 0, p. 143 s.

${ }^{54}$ SANTALUCIA, Giuseppe. Il potere del pubblico ministero, cit., p. 169 (tradução livre).

55 Ainda SANTALUCIA, Giuseppe. Il potere del pubblico ministero, cit., p. 163. Mas dita circunstância é admitida também por DE LEO, Francesco. Il pubblico ministero tra completezza, cit., p. 1440 e CAPRIOLI, Francesco. La ricerca della notizia di reato, cit., p. $441 \mathrm{~s}$.

${ }^{56}$ Sobre o inquerito preliminar italiano, ver: CAPRIOLI, Francesco. Indagini preliminari e udienza preliminare. In: CONSO, Giovanni; GREVI, Vittorio. Compendio di procedura penale, Padova: Cedam, $5^{\circ}$ edição, 2010, p. 612 s. Ver também: FERRUA, Paolo. Il ruolo del giudice nel controllo delle indagini e nell'udienza preliminare. In: PISANI, Mario (org.), Studi in memoria di Pietro Nuvolone, III, Il nuovo processo penale. Studi di diritto straniero e comparato, Milano: Giuffrè, 1991, p. 193 s.

${ }^{57}$ Ver: MAZZA, Oliviero. La fase delle indagini preliminari nel "progetto Alfano" e il suo impatto sul sistema processuale vigente. Cassazione penale, 2009, p. 3265 s.
} 
Revista Eletrônica de Direito Processual - REDP.

Rio de Janeiro. Ano 11. Volume 18. Número 1. Janeiro a Abril de 2017

Periódico Quadrimestral da Pós-Graduação Stricto Sensu em Direito Processual da UERJ

Patrono: José Carlos Barbosa Moreira. ISSN 1982-7636. pp. 118-149

www.redp.uerj.br

razoável suposição da existência de um ilícito? Recorrendo tais condições, existe um dever do ministério publico de iniciar a atividade de busca da notícia de crime ${ }^{58}$, ou então "antes que a notícia de reato surja, existe uma inalienável discricionariedade na escolha do terreno sobre o qual mover a busca dos elementos relacionados ao cometimento de crimes, seja que intervenha diretamente o ministério público ou aja autonomamente a policia judiciaria" ${ }^{" 59}$ ? A atividade de formação da notícia de crime tem natureza administrativa ${ }^{60}$, ou então no novo regime processual, com a alternativa ação/arquivamento colocada ao êxito das investigações preliminares, "toda a fase investigativa antecedente à ação penal [seria entendida] como um continuum", como uma entidade sistematicamente e ontologicamente homogênea "seja que caia depois da jurídica configuração de uma notícia e crime" ${ }^{\text {"61 }}$ ? E ainda: em qual disciplina se embasam as investigações finalizadas à adquirir a notícia de crime? Quais meios de busca podem ser utilizados? Quais traços documentais tem que se deixar nos registros do ministério público $?^{62}$ Quais determinações devem ser adotadas pelo órgão investigador aos seus êxitos? É o caso de marcar como a ausência de indicações normativas a tais fins oferecem ulteriores argumentos a sustentar a tese de quem exclui radicalmente que o ministério público possa efetuar investigações diretas a adquirir a notícia de crime ${ }^{63}$.

Acolhidas tais premissas, é necessário resigna-se não somente diante da ideia de um ágil uso do instrumento do instituto em função de elisão da disciplina dos prazos investigativos, mas também, coerentemente com as indicações provenientes das Secções unidas da Corte de cassação em matéria de arquivamento das não-notícias de crime ${ }^{64}$, a ideia de uma atividade investigativa totalmente subtraída ao controle do juiz se considerada estéril pelo órgão acusador. Para Francesco Caprioli, embora que abstratamente devida, uma tal

\footnotetext{
${ }^{58}$ Como parece sugerir a mesma leitura do art. $330 \mathrm{CPP}$, sobretudo se lida conjuntamente ao disposto no art. 55 CPP italiano, ver: ZAPPULLA, Angelo. Notizia di reato, cit., p. 24.

${ }^{59}$ FERRUA, Paolo. L'iniziativa del pubblico ministero, cit., p. 320. Ver também: LATTANZI, Giorgio. Pubblico ministero e polizia giudiziaria nel d.d.l. n. 1440/S, Cassazione penale, 2009, p. 1786 s.

${ }^{60}$ MAZZA, Oliviero. La fase delle indagini preliminari, cit., 3265 s.; VOENA, Giovanni. Attività investigativa ed indagini preliminari, In: SIRACUSANO, Delfino (org.), Le nuove disposizioni sul processo penale, Atti del convegno di Perugia 14-15 aprile 1988, Padova: Cedam, 1989, p. 29 s.; ZAPPULLA, Angelo. Notizia di reato, cit., p. 27.

${ }^{61}$ DE LEO, Francesco. Il pubblico ministero tra completezza, cit., p. 1441.

${ }^{62}$ Ver também: ORLANDI, Renzo. Nota introduttiva. La ricerca della notizia di reato da parte dell'accusatore, Criminalia, 2011, p. 437 s. e ORLANDI, Renzo. Inchieste preparatorie nei procedimenti di criminalità organizzata: una riedizione dell'inquisitio generalis?, Rivista italiana di diritto e procedura penale, 1996, p. $591 \mathrm{~s}$.

${ }^{63}$ MARANDOLA, Antonella. I registri del pubblico ministero tra notizia di reato ed effetti procedimentali, Padova: Cedam, 2001, p. 86 s.

${ }^{64}$ Assim, Cassação 22 de novembro de 2000, Cassazione penale, 2001, p. 1777 s.
} 
Revista Eletrônica de Direito Processual - REDP.

Rio de Janeiro. Ano 11. Volume 18. Número 1. Janeiro a Abril de 2017

Periódico Quadrimestral da Pós-Graduação Stricto Sensu em Direito Processual da UERJ

Patrono: José Carlos Barbosa Moreira. ISSN 1982-7636. pp. 118-149

www.redp.uerj.br

atividade permaneceria governada pelas escolhas amplamente discricionárias do ministério público, "livre não somente de decidir se, como e quando investigar para transformar a suspeita de crime em notícia de crime, mas também de avaliar a seu gosto os êxitos das investigações" $" 65$.

Para começar, deve-se excluir que, até mesmo em uma perspectiva de reforma a atividade de formação da notícia de crime, possa constituir o fruto de uma autônoma iniciativa do ministério público na falta de "coordenadas de suspeita de culpabilidade"66 já positivamente existente. Pressuposto mínimo para a realização de investigações em questão teria que ser, portanto, a existência de um "suspeito crime" análogo àquele que expressamente impõe ao ministério público, no caso de morte da pessoa, de efetuar verificações direcionadas à adquirir a notícia de crime (art. 116 disposições do CPP italiano). Ocorreria, em outras palavras, uma específica e documentável sugestão informativa inidônea a ingerir o fundamentado convencimento de que o emprego dos recursos investigativos para a busca da notícia de crime não seria vão. Além disto, tratando-se de uma sugestão informativa adquirida pelo ministério público no exercício de suas funções, visto que nem sequer a notícia de crime verdadeira, se adquirida em um contexto extrafuncional, obrigando o procurador a estimular o inicio do inquérito (art. 70, inciso $5^{\circ}$, ordenamento judiciário). Persistindo no plano dos pressupostos, teria que ser considerada a possibilidade de reduzir o poder pre-investigativo do ministério público em determinadas fattispecie de crime, selecionadas com base em sua gravidade ou em sua natureza.

Dito isto, o inquérito direcionado à busca da notícia de crime teria que ser excluído, segundo uma opinião difundida, em primeiro lugar em todas as investigações que comportassem um direto envolvimento do potencialmente indagado ou a restrição dos direitos fundamentais dos indivíduos ${ }^{67}$.

\footnotetext{
${ }^{65}$ CAPRIOLI, Francesco. La ricerca della notizia di reato, cit., p. 445 s. (tradução livre), segundo o qual é necessário reescrever a norma nas suas coordenadas sopraordinadas, para compreender se a extensão dos poderes investigativos do ministério publico na fase que precede a recepção da notícia de crime seja uma solução normativa concebida ou desmentida pelos princípios constitucionais.

${ }^{66}$ DE LEO, Francesco. Il pubblico ministero tra completezza, cit., p. 1447.

${ }^{67}$ ZAPPULLA, Angelo. Notizia di reato, cit., p. 27 s.
} 
Revista Eletrônica de Direito Processual - REDP.

Rio de Janeiro. Ano 11. Volume 18. Número 1. Janeiro a Abril de 2017

Periódico Quadrimestral da Pós-Graduação Stricto Sensu em Direito Processual da UERJ

Patrono: José Carlos Barbosa Moreira. ISSN 1982-7636. pp. 118-149

www.redp.uerj.br

A escolha de não atribuir poderes ao ministério público na fase anterior à tomada de conhecimento da notícia de crime satisfaz uma exigência intuitiva largamente difundida: não incidir sobre os direitos individuais quando ainda se move na órbita da suspeita ${ }^{68}$.

Em relação à exigência de instituir controles sobre a atuação do MP, ele poderia abstratamente traduzir-se em: 1) em primeiro lugar, na previsão de um dever de inscrição da informativa genérica de crime em um registro especifico, distinto daquele reservado às nãonotícias de crime; 2) em segundo lugar, na previsão de um prazo entre o qual teriam que ser feitas as investigações direcionadas à formação da notitia criminis; 3) em terceiro lugar, na previsão de controle hierárquico e/ou jurisdicional tanto sobre a determinação do ministério público de não dar continuidade sobre a informativa genérica, como sobre a determinação do ministério público de não efetuar qualquer inscrição no registro disciplinado no art. 335 CPP ao êxito da atividade pre-investigativa, ou, de qualquer forma, entre o vencimento do $\operatorname{prazo}^{69}$.

\section{Critérios de prioridade: dados normativos, "circolari" e possíveis} perspectivas

Exigências de funcionalidade e efetividade da jurisdição conduziram a uma disciplina legislativa cujo objetivo é introduzir mecanismos em tema de critérios de prioridade no exercício da ação penal e na realização das audiências ${ }^{70}$. As normas de referência são, como é notório, principalmente duas: 1) art. 27 do d.lgs. 51 de 1998 (denominado "reforma sobre o juiz único") e 2) o art. 132-bis disposições que dão atuação ao CPP italiano.

\footnotetext{
${ }^{68}$ Por todos, ver: FERRUA, Paolo. L'iniziativa del pubblico ministero, cit., p. 317 s. e DE LEO, Francesco. Il pubblico ministero tra completezza, cit., p. $1448 \mathrm{~s}$.

${ }^{69}$ Críticas construtivas e contraindicações a estes propósitos são contidas em: FERRUA, Paolo. L'iniziativa del pubblico ministero, cit., p. 319 s. e abundantemente em: CAPRIOLI, Francesco. La ricerca della notizia di reato, cit., p. $447 \mathrm{~s}$.

${ }^{70}$ Abundantemente sobre o assunto: VICOLI, Daniele. Criteri di priorità e meccanismi sospensivi: un difficile connubio in tema di accelerazione dei tempi processuali - Sezione seconda: Un mosaico normativo dagli incerti esiti applicativi. In: MAZZA, Oliviero; VIGANO', Francesco (org.). Misure urgenti in materia di sicurezza pubblica (d.l. 23 maggio 2008, n. 92 conv. in legge 24 luglio 2008, n. 125), Torino: Giappichelli, 2008, p. 371 - 399; VICOLI, Daniele. Scelte del pubblico ministero nella trattazione delle notizie di reato e art. 112 cost.: un tentativo di razionalizzazione, em Rivista italiana di diritto e procedura penale, 2003, p. 251 s. e VICOLI, Daniele. L'esperienza dei criteri di priorità nell'esercizio dell'azione penale: realtà e prospettive. In: DI CHIARA, Giuseppe (org.), Il processo penale tra politiche della sicurezza e nuovi garantismi, Torino: Giappichelli, 2003, p. 225-262.
} 
Revista Eletrônica de Direito Processual - REDP.

Rio de Janeiro. Ano 11. Volume 18. Número 1. Janeiro a Abril de 2017

Periódico Quadrimestral da Pós-Graduação Stricto Sensu em Direito Processual da UERJ

Patrono: José Carlos Barbosa Moreira. ISSN 1982-7636. pp. 118-149

www.redp.uerj.br

Originalmente uma norma transitória, o primeiro dispositivo estabelece uma

disciplina de tipo geral que tem que ser seguida em matéria de organização das audiências: de fato, o juiz tem que levar em consideração a gravidade e a concreta ofensividade do crime, do prejuízo que poderia derivar o atraso para a formação da prova e para o accertamento dos fatos e do interesse da pessoa lesada ${ }^{71}$.

O segundo, ao invés, estabelece um catálogo mais analítico dos processos que devem ser tratados prioritariamente. Segundo esta norma, tem preferência absoluta por título de crime: 1) delitos de associação mafiosa ou criminal, delitos em tema de prevenção dos infortúnios no trabalho e em matéria de higiene, crimes cometidos em matéria de circulação no trânsito e imigração; 2) pelo quantum de pena, onde esta não seja inferior no máximo a quatro anos; 3) enfim, processos contra detidos ou submetidos a medidas precautelares ou cautelares.

Contudo, diante de uma disciplina legislativa lacunosa e nem sempre correspondente a critérios de coerência, os instrumentos mais importantes para o estudo prático dos critérios de prioridade permanecem as circolari emitidas pelos chefes de procuradorias territoriais. A primeira iniciativa que introduziu um critério de trabalho baseado em indicações "prioritárias" é a "circolare" Zagrebelsky ${ }^{72}$. O documento, cuja finalidade era disciplinar os procedimentos organizativos da "Procura della Repubblica presso la Pretura circondariale di Torino", indicou verdadeiras estradas preferenciais para algumas tipologias de notícia de crime. Com base em tal tomada de posição, diversos procuradores dirigentes deram vida a uma intensa atividade para-legislativa que foi substancialmente avalizada pelo "Consiglio Superiore della Magistratura",73.

Merece também particular menção a "circolare Maddalena" "74: trata-se de ato com o qual são ditadas instruções internas às procuradorias cuja finalidade é organização dos procedimentos por meio de um catalogo predeterminado de crimes marginais.

Chamado a se pronunciar sobre a "circolare Maddalena", o "Consiglio Superiore

\footnotetext{
71 Ver: FERRUA, Paolo. Studi sul processo penale. Anamorfosi del processo accusatorio, II, Torino: Giappichelli, 1992.

${ }^{72}$ Uma filosofia de organização do trabalho para o tratamento das questões penais, publicada em: Cassazione penale, 1991, p. $362 \mathrm{~s}$.

73 Veja-se, por exemplo: "Procura della Repubblica di Torino", circolare 8 de março de 1989 ("circolare Pieri”). Cassazione penale, 1989, p. 1616 s.

74 “Procura della Repubblica di Torino", circolare 10 de janeiro de 2007, numero 50. Questione giustizia, 2007, p. $619 \mathrm{~s}$.
} 
Revista Eletrônica de Direito Processual - REDP.

Rio de Janeiro. Ano 11. Volume 18. Número 1. Janeiro a Abril de 2017

Periódico Quadrimestral da Pós-Graduação Stricto Sensu em Direito Processual da UERJ

Patrono: José Carlos Barbosa Moreira. ISSN 1982-7636. pp. 118-149

www.redp.uerj.br

della Magistratura" afirmou a importância do poder-dever do bom dirigente em individuar critérios de prioridade dos procedimentos penais: de fato, eles devem ser considerados não apriorísticas renúncias de agir, mas como princípios de boa organização do trabalho. Presume-se, portanto, uma certa discricionariedade do ministério público, que na "circolare Zagrebelsky" encontra máxima expansão ${ }^{75}$.

Com base nos mesmos princípios, diferentes procuradorias italianas optaram pela adoção e relativa publicação dos critérios de prioridade na formação e/ou no exercício da ação penal. Na maior parte dos casos, os tribunais tendem a reproduzir, quase textualmente, os critérios indicados no art. 132-bis das disposições de atuação do CPP italiano, embora que não faltem soluções originais. A este proposito lembra-se, por exemplo, a "circolare" de 12 de dezembro de 2008 do presidente da "corte d'appello" de Milão ${ }^{76}$ que estabelecia uma estrada preferencial para algumas categorias de processos, como aqueles inerentes a imputados submetidos a medidas privativas da liberdade pessoal ou concernentes a crimes considerados graves até mesmo em relação à espera social de justiça. Dita circular previa também critérios "negativos" a fim de evitar processos cuja inutilidade prática parecia ser evidente. Assim, previa-se por exemplo que "não [fossem] considerados prioritários" os processos destinados a se extinguir por prescrição próxima, ou no arco de seis meses, ou processos cujo objeto fossem crimes cuja pena seria inteiramente extinguível por benefícios legislativos.

Questiona-se, portanto, se é sustentável uma tal autonomia e diferenciação de disciplinas, e, sobretudo, se isso é coerente com a ratio do art. 112 Const., de igualdade e legalidade, além da independência dos procuradores.

O quadro exposto, no qual se insere o recurso a critérios de prioridade por parte dos órgãos requerentes, por meio de uma política que parece destinada a ser recebida legislativamente, denota a perene crise da obrigatoriedade da ação penal no ordenamento italiano. Por outro lado, a consciência de que tal obrigatoriedade seja destinada a conviver com espaços para decisões do MP em relação à não acusação, previsíveis e controláveis, é há muito tempo fundamentada. De fato, para incrementar as reduzidas capacidades de eliminação do sistema, o caminho da despenalização e da desprocessualização devem ser

\footnotetext{
${ }^{75}$ Sobre isto, ver: KOSTORIS, Roberto E. Per un'obbligatorietà temperata dell'azione penale. Rivista di diritto processuale, 2007, p. $879 \mathrm{~s}$.

${ }^{76}$ Disponível em: <www.ilsole24ore.it>. Acesso em: 4 mar. 2017. Com síntese de: NEGRI, Giovanni. Milano detta le priorità per i processi penali. Il Sole-24 Ore, 5 de fevereiro de 2009, p. 20.
} 
Revista Eletrônica de Direito Processual - REDP.

Rio de Janeiro. Ano 11. Volume 18. Número 1. Janeiro a Abril de 2017

Periódico Quadrimestral da Pós-Graduação Stricto Sensu em Direito Processual da UERJ

Patrono: José Carlos Barbosa Moreira. ISSN 1982-7636. pp. 118-149

www.redp.uerj.br

necessariamente percorridas ${ }^{77}$. Porém, seria ilusório pensar em eliminar desta forma a decisão do MP na gerência das notícias de crime. Ainda que se possa limitar o número de crimes e ampliar a hipótese de arquivamento, é necessário que permaneçam espaços avaliativos suscetíveis de serem preenchidos pelo MP com escolhas orientadas por parâmetros objetivos e definidos por opções de política criminal.

\section{Considerações Finais}

As afirmações que precedem são, todavia, destinadas a assumir um valor suscetível de modificações no tempo ${ }^{78}$, não apenas se se considerar que permanece uma relação de grave desequilíbrio entre os recursos operativos dos quais dispõem os procuradores e o número das notícias de crime que chegam quotidianamente. Deste ponto de vista, a situação não parece ser diferente comparada ao passado: os órgãos do ministério público continuam a se encontrar, de fato, na material impossibilidade de examinar todas as denúncias de crime das quais são destinatários. Como consequência, o sistema é obrigado a tolerar práxis certamente lesivas ao princípio de obrigatoriedade: como foi dito com eficaz síntese, "quotidianamente, nas procuradorias, escolhas são feitas entre os vários ilícitos denunciados, guiadas por critérios cronológicos ou pela gravidade do bem tutelado ou pelas inclinações pessoais (ideológicas, políticas ou econômicas) de cada acusador enquanto 'os fatos não escolhidos' encontram a 'natural' prescrição"79.

Se isso for verdade, parece evidente que as ameaças mais graves à regra da obrigatoriedade da ação penal derivam não tanto do possível mal funcionamento do mecanismo do arquivamento, mas da atual impossibilidade de expugnar a inércia oculta, não declarada, do ministério público. Permanecendo inalterado a atual carga de trabalho das procuradorias, não é de fato pensável que os instrumentos predispostos a tal fim pelo legislador possam fornecer resultados verdadeiramente significativos. Não assusta, portanto,

\footnotetext{
${ }^{77}$ Nessa direção se inserem as recentes intervenções legislativas em matéria de procedimento contra ausentes, suspensão do procedimento e período de prova por irrelevância do fato (além das despenalizações e da sanção cível punitiva).

${ }^{78}$ Em termos mais amplos, ver: ILLUMINATI, Giulio. I principi generali del sistema processuale penale italiano, Pol. Dir., 1999, p. 301 s.

${ }^{79}$ VITALONE, Claudio. La funzione d'accusa tra obbligatorietà e discrezionalità. In: GAITO, Alfredo (org.). Accusa penale e ruolo del pubblico ministero: atti del Convegno: Perugia, 20-21 aprile 1990, Napoli: Jovene, 1991, p. 294.
} 
Revista Eletrônica de Direito Processual - REDP.

Rio de Janeiro. Ano 11. Volume 18. Número 1. Janeiro a Abril de 2017

Periódico Quadrimestral da Pós-Graduação Stricto Sensu em Direito Processual da UERJ

Patrono: José Carlos Barbosa Moreira. ISSN 1982-7636. pp. 118-149

www.redp.uerj.br

que a doutrina processualística continue a questionar sobre a efetiva renunciabilidade do princípio contido no art. 112 Const.

Como é notório, segundo uma difundida visão seria indispensável conformar-se à falência da orientação constitucional, introduzindo, como critério guia para as escolhas do ministério publico, o oposto princípio de oportunidade, e submetendo a operação das procuradorias à direção de um órgão de natureza política. Deste modo, as escolhas de política criminal que hoje são ocultamente efetuadas pelos dirigentes das procuradorias reentrariam na fisiologia do sistema, e, sobretudo, seriam sindicáveis em sede política: assim restaria definitivamente banido pelo ordenamento constitucional o paradoxo de um órgão do estado que, como o ministério público, age politicamente sem ser politicamente responsável ${ }^{80}$.

A tal proposta se apresentam críticas, entre outras, de modo totalmente convincente, sublinhando tanto a fraca efetividade da solução proposta, como os graves riscos de prevaricação do poder político sobre o judiciário que dela derivariam. Dito isto, o acento põe-se sobre a necessidade de reconduzir a uma situação de normalidade o nível do trabalho dos procuradores, garantindo assim - em primeiro lugar, por meio de uma corajosa política de despenalização - as condições indispensáveis para um efetivo respeito do princípio constitucional $^{81}$.

Essa discussão é muito vasta e delicada para ser enfrentada neste trabalho, considerando suas pretensões diversas ${ }^{82}$. Ocorre dizer, todavia, que se vai cada vez mais afirmando uma postura interpretativa que se pode definir intermédia em relação às duas expostas acima, segundo a qual é necessário prestar atenção a interpretações excessivamente rígidas do art. 112 Const. e apontar, com base em uma leitura "corajosamente aberta" da norma constitucional, novos remédios processuais e extraprocessuais capazes de reorientar

\footnotetext{
${ }^{80}$ Veja-se DE LUCA, Giuseppe. Controlli extra-processuali ed endo-processuali nell'attività inquirente del pubblico ministero. In: GAITO, Alfredo (org.). Accusa penale e ruolo del pubblico ministero: atti del Convegno: Perugia, 20-21 aprile 1990, Napoli: Jovene, 1991, p. 56; NEPPI MODONA, Guido; VIOLANTE, Luciano. Poteri dello Stato e sistema penale. Corso di lezioni universitarie, Torino: Tirrenia Stampatori, 1978, p. 325 s.; NOBILI, Massimo. Nuovi modelli e connessioni: processo - teoria dello stato - epistemologia, Indice penale, 1999, p. 33 s. e NOBILI, Massimo. Il magistrato in funzione di polizia tributaria: una ulteriore "supplenza" conforme alle norme vigenti?, Legislazione Penale, 1986, p. 313 s.

${ }^{81}$ Ver: ZAGREBELSKY, Vladimiro. Stabilire le priorità nell'esercizio obbligatorio dell'azione penale. In: FILIPPI, Camilla (org.), Il pubblico ministero oggi, Milano: Giuffrè, 1994, p. 10 s.; CAPRIOLI, Francesco. L'archiviazione, cit., p. 595 s. e GUARNIERI, Carlo. Pubblico ministero e sistema politico, Padova: Cedam, 1984.

${ }^{82}$ Veja-se: GREVI, Vittorio. Garanzie soggettive e garanzie oggettive nel processo penale secondo il progetto della Commissione Bicamerale per le riforme costituzionali. In: GREVI, Vittorio (org.). Alla ricerca di un processo penale "giusto", Milano: Giuffrè, 2000, $183 \mathrm{~s}$.
} 
Revista Eletrônica de Direito Processual - REDP.

Rio de Janeiro. Ano 11. Volume 18. Número 1. Janeiro a Abril de 2017

Periódico Quadrimestral da Pós-Graduação Stricto Sensu em Direito Processual da UERJ

Patrono: José Carlos Barbosa Moreira. ISSN 1982-7636. pp. 118-149

www.redp.uerj.br

a ideia de obrigatoriedade ${ }^{83}$. Nessa perspectiva, as soluções propostas são essencialmente duas.

A primeira, muito notória, é aquela que consiste em permitir aos representantes do ministério público selecionar legitimamente as notícias de crime a serem tratadas com precedência em relação às demais, com base em "critérios de prioridade" que seriam especificamente estabelecidos em sede parlamentar, e em execução de programas operativos periodicamente estabelecidos pelos dirigentes de procuradoria de acordo com aqueles critérios $^{84}$. Como é fácil imaginar, é uma proposta que suscita numerosos problemas: até mesmo além da compatibilidade de dito sistema com o princípio de obrigatoriedade contido no artigo 112 Const., ocorre perguntar-se, por exemplo, se as diretivas apresentadas em sede política e os consequentes "programas de ação" das procuradorias teriam que se tornar públicos (sobretudo para garantir o controle sobre seu efetivo respeito) ${ }^{85}$ ou mantidos em segredo (para não incidir sobre idêntico âmbito das normas incriminadoras, substancialmente autorizando os cidadãos a delinquir) ${ }^{86}$; nem se compreende qual lugar ocupariam as "linhas-guia" de política criminal na hierarquia das fontes normativas, visto que a observância de tais prescrições determinariam, de fato, a inaplicação da lei penal ${ }^{87}$. Sem contar, enfim, que a adesão a este tipo de perspectiva comportaria não somente uma definitiva renúncia àquela personalização da atividade acusatória que era considerada um instrumento irrenunciável de resguardo do dever de agir ${ }^{88}$, mas também o inevitável abandono, por parte dos procuradores, de sua preciosa função de tutela das minorias no respeito da legalidade.

A segunda solução - de maior interesse aos nossos fins - é representada pela possível ampliação normativa dos pressupostos de operabilidade do arquivamento, sobre o modelo de análogas reformas já experimentados com sucesso em outros ordenamentos

\footnotetext{
${ }^{83}$ CHIAVARIO, Mario. L'obbligatorietà dell'azione penale, cit., p. 2668, de onde foi tirada a citação trazida no texto, e BOTTI, Claudio. Il principio di obbligatorietà dell'azione penale oggi: confini e prospettive, Criminalia, 2010, p. 327 s.

${ }^{84}$ CAPRIOLI, Francesco. L'archiviazione, cit., p. 596 s. e BORRACCETTI, Vittorio. Archiviazione, indagini preliminari e obbligatorietà dell'azione penale, Quest. giust., 1989, p. 576 s.

85 Ver: ZAGREBELSKY, Vladimiro. Stabilire le priorità nell'esercizio, cit. p. 17 nota numero 33.

${ }^{86}$ CHIAVARIO, Mario. Obbligatorietà dell'azione, cit., p. 2673 s.

${ }^{87}$ Nesta mesma direção: CAPRIOLI, Francesco. L'archiviazione, cit., p. 598 s.

${ }^{88}$ CAPRIOLI, Francesco. L'archiviazione, cit., p. 599 s.
} 
Revista Eletrônica de Direito Processual - REDP.

Rio de Janeiro. Ano 11. Volume 18. Número 1. Janeiro a Abril de 2017

Periódico Quadrimestral da Pós-Graduação Stricto Sensu em Direito Processual da UERJ

Patrono: José Carlos Barbosa Moreira. ISSN 1982-7636. pp. 118-149

www.redp.uerj.br

estrangeiros ${ }^{89}$. Nesta direção, reentra a recente introdução do proscioglimento por particular

pouca gravidade do fato ${ }^{90}$.

Dito proscioglimento per tenuidade - que pressupõe a existência de um fato típico de crime, de modesta expressividade lesiva mas não totalmente inofensivo ${ }^{91}$ - responde a duas fundamentais exigências constitucionais: 1) o principio de proporcionalidade da intervenção repressiva penal, que proíbe, em conformidade com o cânone da ultima ratio, sancionar penalmente condutas que parecem não merecedoras de pena no caso especifico ${ }^{92}$, e torna a declaração por tenuidade do fato uma verdadeira e própria "necessidade de justiça" em consideração da "adquirida consciência dogmática dos limites da tipicidade penal"93; 2) a exigência de aliviar a sobrecarga do judiciário e de devolver efetividade ao principio de obrigatoriedade da ação penal ${ }^{94}$.

Diante do exposto, retoma-se o problema inicialmente definido como orientação deste artigo: é sustentável a ideia de uma obrigatoriedade absoluta, que determine um dever de acusação pública em todos os casos de ocorrência de um crime e de existência elementos suficientes para a sua comprovação? Assim, a partir da análise do panorama italiano, que fundamentalmente aporta contribuições deslocáveis ao cenário brasileiro, pode-se concluir

\footnotetext{
${ }^{89}$ CHIAVARIO, Mario. Obbligatorietà dell'azione, cit., p. $2670 \mathrm{~s}$.

90 Trata-se, de fato, de um instituto como aquele do arquivamento consequente à declaratória de exclusão da punibilidade por particular tenuidade do fato previsto no ordenamento italiano nos procedimentos contra menores (art. 27 do D.p.R 22 de setembro de 1988, n. 448) e diante ao giudice de pace (art. 34 do d.lgs. 28 de agosto de 2000, n. 274) e agora estendido ao rito ordinário pelo d.lgs. 16 de março de 2015, n. 28, que introduziu o art. 131-bis c.p. italiano. Assim já: CAPRIOLI, Francesco. L'archiviazione, cit., p. 600 s. e, recentemente, CAPRIOLI, Francesco. Prime considerazioni sul proscioglimento per particolare tenuità del fatto, 2015. Disponível em: <www.penalecontemporaneo.it>. Acesso em: 4 mar. 2017. Ver também: CAPRIOLI, Francesco. Due iniziative di riforma nel segno della deflazione: la sospensione del procedimento con messa alla prova dell'imputato maggiorenne e l'archiviazione per tenuità del fatto, em Cassazione penale, 2012, p. 17 s.; CAPRIOLI, Francesco; MELILLO, Giovanni; RUGGIERI; Francesca; SANTALUCIA, Giuseppe. Sulla possibilità di introdurre nel processo penale ordinario l'istituto della declaratoria di particolare tenuità del fatto riflessioni a margine di una recente proposta, Cassazione penale, 2006, p. 3496 s.; CORDERO, Franco. Oltre il 'patteggiamento' per i reati bagatellari? La limitata discrezionalità dell'azione penale operante nell'ordinamento tedesco-federale e il 'nostro' art. 112 Cost., em Legislazione penale, 1986, 688 s.; CESARI, Claudia. Le clausole di irrilevanza del fatto nel sistema processuale penale, Torino: Giappichelli, 2005 e QUATTROCOLO, Serena. Esiguità del fatto e regole per l'esercizio dell'azione penale, Napoli: Jovene, 2004. ${ }^{91}$ Em geral, sobre as relações entre ofensividade e tenuidade, ver: QUATTROCOLO, Serena. Esiguità del fatto e regole per l'esercizio dell'azione penale, Torino: Giappichelli, 2004, p. 113 s.

${ }^{92}$ Ver: CAPRIOLI, Francesco. Prime considerazioni sul proscioglimento per particolare tenuità del fatto, 2015. Disponível em: <www.penalecontemporaneo.it>, p. 2 s.

${ }^{93}$ PALAZZO, Francesco. Nel dedalo delle riforme prossime e venture, Rivista italiana di diritto e procedura penale, 2014, p. $1706 \mathrm{~s}$.

${ }^{94}$ Se falava já em: CAPRIOLI, Francesco; MELILLO, Giovanni; RUGGIERI; Francesca; SANTALUCIA, Giuseppe. Sulla possibilità di introdurre nel processo penale ordinario l'istituto della declaratoria di particolare tenuità del fatto riflessioni a margine di una recente proposta, Cassazione penale, 2006, p. 3495.
} 
Revista Eletrônica de Direito Processual - REDP.

Rio de Janeiro. Ano 11. Volume 18. Número 1. Janeiro a Abril de 2017

Periódico Quadrimestral da Pós-Graduação Stricto Sensu em Direito Processual da UERJ

Patrono: José Carlos Barbosa Moreira. ISSN 1982-7636. pp. 118-149

www.redp.uerj.br

que: 1) é insustentável uma ideia de obrigatoriedade absoluta, pois na prática ela não é realizável e acaba por ocasionar violações à própria premissa de igualdade de tratamento aos cidadãos (que paradoxalmente é uma de suas principais fundamentações), pois a decisão sobre acusar ou não finda por se tornar individual e potencialmente arbitrária por cada representante do MP; 2) então, devem ser previstos espaços para racionalização do poderdever de acusar do MP, ${ }^{95}$ por critérios distintos à exclusiva ocorrência de um crime e de elementos suficientes para a sua comprovação; e, 3) tais critérios, contudo, devem ser regulados de um modo a poderem ser generalizáveis e controláveis, com pressupostos objetivos e taxativos, assim respeitando a necessidade de igualdade de tratamento entre os cidadãos.

\section{REFERÊNCIAS BIBLIOGRÁFICAS.}

BORRACCETTI, Vittorio. Archiviazione, indagini preliminari e obbligatorietà dell'azione penale, Quest. giust., 1989, p. 576 s.

BOTTI, Claudio. Il principio di obbligatorietà dell'azione penale oggi: confini e prospettive, Criminalia, 2010, p. 327 s.

CAIANIELLO, Michele. Poteri dei privati nell'esercizio dell'azione penale, Torino: Giappichelli, 2003.

CAIANIELLO, Michele. L'esercizio dell'azione penale nella Corte penale internazionale, Rivista di diritto processuale, 2001, n. 1, p. 200 s.

CAIANIELlO, Michele. Archiviazione (dir. proc. pen.), Enc. Dir., Annali, II, t. 1, Milano: Giuffrè, 2008, 64 s.

\footnotetext{
95 “A oportunidade (ou não-obrigatoriedade) se caracteriza em oposição à obrigatoriedade, visto que autoriza o não oferecimento da denúncia ou a suspensão do processo penal conforme opção do órgão acusador estatal (em regra sob a anuência da defesa) com fundamento em critérios utilitários, político-criminais, econômicos, etc., em situação cujo lastro probatório é suficiente para atestar a materialidade e a autoria de um crime. Tais parâmetros decisórios podem ser taxativamente previstos em lei, em um cenário de atenção ao princípio da legalidade, ou flexíveis à ampla discricionariedade do acusador. Por certo que somente a primeira opção é aceitável no processo penal democrático." (VASCONCELLOS, Vinicius G. Barganha e Justiça Criminal Negocial. São Paulo: IBCCRIM, 2015. p. 48-49). Deve-se, contudo, distinguir os espaços de nãoobrigatoriedade em que o acusador público finda por não iniciar a persecução penal daqueles em que há um acordo entre acusação e defesa para imposição de uma pena reduzida a partir da conformidade do acusado, $o$ que finda por reproduzir e ampliar acriticamente o ciclo vicioso da expansão do direito penal. Sobre isso, ver: VASCONCELLOS, Vinicius G.; CAPPARELLI, Bruna. Barganha no processo penal italiano: análise crítica do patteggiamento e das alternativas procedimentais na justiça criminal. Revista Eletrônica de Direito Processual, vol. 15, p. 435-453, jan./jun. 2015.
} 
Revista Eletrônica de Direito Processual - REDP.

Rio de Janeiro. Ano 11. Volume 18. Número 1. Janeiro a Abril de 2017

Periódico Quadrimestral da Pós-Graduação Stricto Sensu em Direito Processual da UERJ

Patrono: José Carlos Barbosa Moreira. ISSN 1982-7636. pp. 118-149

www.redp.uerj.br

CALAMANDREI, Piero. La relatività del concetto di azione, Rivista di diritto processuale civile, 1939, I, 22.

CALAMANDREI, Piero. Relazione preliminare sul tema «Posizione costituzionale del potere giudiziario nella nuova Costituzione italiana». In: D’ALESSIO, Gianfranco (org.), Alle origini della Costituzione italiana. I lavori preparatori della Commissione per studi attinenti alla riorganizzazione dello Stato. 1945-1946, Bologna: il Mulino, 1979, p. 623.

CAPRIOLI, Francesco. Prime considerazioni sul proscioglimento per particolare tenuità del fatto, 2015. Disponível em: <www.penalecontemporaneo.it>. Acesso em: 4 mar. 2017.

CAPRIOLI, Francesco. Due iniziative di riforma nel segno della deflazione: la sospensione del procedimento con messa alla prova dell'imputato maggiorenne e l'archiviazione per tenuità del fatto, Cassazione penale, 2012, p. 17 s.

CAPRIOLI, Francesco. La ricerca della notizia di reato da parte dell'accusatore, Criminalia, 2011, p. 439 s.

CAPRIOLI, Francesco. Indagini preliminari e udienza preliminare. In: CONSO, Giovanni; GREVI, Vittorio. Compendio di procedura penale, Padova: Cedam, $5^{\circ}$ edição, 2010, p. $612 \mathrm{~s}$.

CAPRIOLI, Francesco. L'azione penale privata e la tutela della persona offesa. In: ZAPPALÀ, Vincenzo (org.), Azione civile e prescrizione processuale nella bozza di riforma della Commissione Riccio, Torino: Giappichelli, 2010, p. 26 s.

CAPRIOLI, Francesco; MELILLO, Giovanni; RUGGIERI; Francesca; SANTALUCIA, Giuseppe. Sulla possibilità di introdurre nel processo penale ordinario l'istituto della declaratoria di particolare tenuità del fatto riflessioni a margine di una recente proposta, Cassazione penale, 2006, p. 3496 s.

CAPRIOLI, Francesco. Il processo penale dopo la legge Carotti, Commento agli artt. 25-26, em Diritto penale e processo, 2000, p. 291 s.

CAPRIOLI, Francesco. L'archiviazione, Napoli: Jovene, 1994.

CARRARA, Francesco. Azione penale, Rivista penale, II (1875), vol. III (I s.), p. 18.

CARRARA, Francesco. Progresso e regresso del giure penale nel nuovo Regno d'Italia osservato nella dottrina, nella legislazione e nella giurisprudenza. In: CARRARA, Francesco, Opuscoli di diritto criminale, vol. IV, Lucca: Tipografia Giusti, 1874, p. 44 s.

CESARI, Claudia. Le clausole di irrilevanza del fatto nel sistema processuale penale, Torino: Giappichelli, 2005. 
Revista Eletrônica de Direito Processual - REDP.

Rio de Janeiro. Ano 11. Volume 18. Número 1. Janeiro a Abril de 2017

Periódico Quadrimestral da Pós-Graduação Stricto Sensu em Direito Processual da UERJ

Patrono: José Carlos Barbosa Moreira. ISSN 1982-7636. pp. 118-149

www.redp.uerj.br

CHIAVARIO, Mario. Profili del principio costituzionale di obbligatorietà dell'azione penale. In: CHIAVARIO, Mario, L'azione penale tra diritto e politica, Padova: Cedam, $1995,55 \mathrm{~s}$.

CHIAVARIO, Mario. L'obbligatorietà dell'azione penale: il principio e la realtà, Cassazione penale, 1993, p. $2660 \mathrm{~s}$.

CHIAVARIO, Mario. Appunti sulla problematica dell'“azione" nel processo penale italiano: incertezze, prospettive, limiti, Rivista trimestrale di diritto e procedura civile, 1975, $\mathrm{p}$. $905 \mathrm{~s}$.

CONSIGLIO SUPERIORE DELLA MAGISTRATURA. Procura della Repubblica di Torino, circolare 8 marzo 1989 ("circolare Pieri"). Cassazione penale, 1989, $1616 \mathrm{~s}$.

CORDERO, Franco. Oltre il 'patteggiamento' per i reati bagatellari? La limitata discrezionalità dell'azione penale operante nell'ordinamento tedesco-federale e il 'nostro' art. 112 Cost., Legislazione penale, 1986, $688 \mathrm{s.}$

CORDERO, Franco. Le situazioni soggettive nel processo penale, Torino: Giappichelli, 1957.

COUTINHO, Jacinto Miranda. Introdução aos princípios gerais do direito processual penal brasileiro. Revista de Estudos Criminais, São Paulo, n. 01, p. 26-51, 2001.

DE LEO, Francesco. Il pubblico ministero tra completezza investigativa e ricerca dei reati, Cassazione penale, 1995, p. $1431 \mathrm{~s}$.

DE LUCA, Giuseppe. Controlli extra-processuali ed endo-processuali nell'attività inquirente del pubblico ministero. In: GAITO, Alfredo (org.). Accusa penale e ruolo del pubblico ministero: atti del Convegno: Perugia, 20-21 aprile 1990, Napoli: Jovene, 1991, p. 56.

DI CHIARA, Giuseppe. Il pubblico ministero e l'esercizio dell'azione penale. In: FIANDACA, Giovanni; DI CHIARA, Giuseppe. Una introduzione al sistema penale, Napoli, 2003, p. 235 e s.

FERNANDES, Antonio Scarance. Teoria Geral do Procedimento e O Procedimento no Processo Penal. São Paulo: RT, 2005.

FERRUA, Paolo. Studi sul processo penale. Anamorfosi del processo accusatorio, II, Torino: Giappichelli, 1992.

FERRUA, Paolo. Il ruolo del giudice nel controllo delle indagini e nell'udienza preliminare. In: PISANI, Mario (org.), Studi in memoria di Pietro Nuvolone, III, Il nuovo processo 
Revista Eletrônica de Direito Processual - REDP.

Rio de Janeiro. Ano 11. Volume 18. Número 1. Janeiro a Abril de 2017

Periódico Quadrimestral da Pós-Graduação Stricto Sensu em Direito Processual da UERJ Patrono: José Carlos Barbosa Moreira. ISSN 1982-7636. pp. 118-149

www.redp.uerj.br

penale. Studi di diritto straniero e comparato, Milano: Giuffrè, 1991, p. 193 s.

FERRUA, Paolo. L'iniziativa del pubblico ministero nella ricerca della notitia criminis, Legislazione penale, 1986, p. 313 s.

GAZOTO, Luís Wanderley. O Princípio da Não-Obrigatoriedade da Ação Penal Pública.

Uma crítica ao formalismo no Ministério Público. Barueri: Manole, 2003.

GIACOMOLLI, Nereu José. Legalidade, Oportunidade e Consenso no Processo Penal na

Perspectiva das Garantias Constitucionais. Porto Alegre: Livraria do Advogado, 2006.

GIALUZ, Mitja. Art. 112. In: BARTOLI, Roberto; BIN, Roberto (org.), Commentario breve alla Costituzione, Padova: Cedam, 2008, p. 1011 s.

GIOSTRA, Glauco. Indagine e prova: dalla non dispersione a nuovi scenari cognitivi. In:

GALATI, Antonio (org.), Verso la riscoperta di un modello processuale. Atti del Convegno in memoria di Antonino Galati (Caserta, 12-14 ottobre 2001), Milano: Giuffrè, 2003, p. 47 s.

GIOSTRA, Glauco. Pubblico ministero e polizia giudiziaria, Giustizia Insieme, 2008, 0, p. $143 \mathrm{~s}$.

GIOSTRA, Glauco. L'archiviazione. Lineamenti Sistematici e questioni interpretative, Torino: Giappichelli, 1994.

GIULIANI, Livia. La regola di giudizio in materia di archiviazione (art. 125 disp. att. c.p.p.), Cassazione penale, 1992, p. 249 s.

GREVI, Vittorio. Ruolo del pm, polizia giudiziaria e rischi di interferenze politiche, Corriere della sera, 16 de julho de 2009.

GREVI, Vittorio. Garanzie soggettive e garanzie oggettive nel processo penale secondo il progetto della Commissione Bicamerale per le riforme costituzionali. In: GREVI, Vittorio (org.). Alla ricerca di un processo penale “giusto”, Milano: Giuffrè, 2000, 183 s.

GREVI, Vittorio. Archiviazione per “inidoneità probatoria” ed obbligatorietà dell'azione penale. Rivista italiana di diritto e procedura penale, 1990, p. $1274 \mathrm{~s}$.

GUARNIERI, Carlo. Pubblico ministero e sistema politico, Padova: Cedam, 1984.

KOSTORIS, Roberto E. Per un'obbligatorietà temperata dell'azione penale, Rivista di diritto processuale, 2007, p. 875 s.

ILLUMINATI, Giulio. I principi generali del sistema processuale penale italiano, Pol. Dir., 1999, p. $301 \mathrm{~s}$. 
Revista Eletrônica de Direito Processual - REDP.

Rio de Janeiro. Ano 11. Volume 18. Número 1. Janeiro a Abril de 2017

Periódico Quadrimestral da Pós-Graduação Stricto Sensu em Direito Processual da UERJ

Patrono: José Carlos Barbosa Moreira. ISSN 1982-7636. pp. 118-149

www.redp.uerj.br

INSOLERA, Gaetano. La ricerca della notizia di reato da parte dell'accusatore, Criminalia, 2011, p. 452 s.

JARDIM, Afrânio Silva. Ação penal pública: princípio da obrigatoriedade. $3^{\mathrm{a}}$ ed. Rio de Janeiro: Forense, 1998.

LATTANZI, Giorgio. Pubblico ministero e polizia giudiziaria nel d.d.1. n. 1440/S, Cassazione penale, 2009, p. 1786 s.

LUPARIA, Luca. Obbligatorietà e discrezionalità dell'azione penale nel quadro comparativo europeo, Giurisprudenza italiana, 2002, p. 8 s.

MANZIANI, Domanico. Il principio di obbligatorietà dell'azione penale oggi: confini e prospettive, Criminalia, 2010, p. 332 s.

MARANDOLA, Antonella. I registri del pubblico ministero tra notizia di reato ed effetti procedimentali, Padova: Cedam, 2001, 86 s.

MARZADURI, Enrico. Il principio di obbligatorietà dell'azione penale oggi: confini e prospettive, Criminalia, 2010, p. 337 s.

MARZADURI, Enrico. Considerazioni sui profili di rilevanza processuale del principio di obbligatorietà dell'azione penale a vent'anni dalla riforma del codice di procedura penale. In: PACE, Alessandro; BARTOLE, Sergio; ROMBOLI, Roberto (org.), Problemi attuali della giustizia in Italia, Napoli: Jovene, 2010, 124 s.

MAZZA, Oliviero. La fase delle indagini preliminari nel "progetto Alfano" e il suo impatto sul sistema processuale vigente, em Cassazione penale, 2009, p. 3265 s.

MELILLO, Giovanni. Le operazioni sotto copertura nelle indagini relative a delitti con finalità di terrorismo. In: DI CHIARA, Giuseppe (org.), Il processo penale tra politiche della sicurezza e nuovi garantismi, Torino: Giappichelli, 2002, p. 33 s.

NEGRI, Giovanni. Milano detta le priorità per i processi penali, em Il Sole-24 Ore, 5 de fevereiro de 2009, p. 20.

NEPPI MODONA, Guido; VIOLANTE, Luciano. Poteri dello Stato e sistema penale. Corso di lezioni universitarie, Torino: Tirrenia Stampatori, 1978, p. 325 s.

NOBILI, Massimo. Nuovi modelli e connessioni: processo - teoria dello stato epistemologia, em Indice penale, 1999, p. 33 s.

NOBILI, Massimo. Il magistrato in funzione di polizia tributaria: una ulteriore "supplenza" conforme alle norme vigenti?, Legislazione Penale, 1986, p. 313 s.

NOBILI, Massimo. La nuova procedura penale. Lezioni agli studenti, Bologna: Clueb, 1989. 
Revista Eletrônica de Direito Processual - REDP.

Rio de Janeiro. Ano 11. Volume 18. Número 1. Janeiro a Abril de 2017

Periódico Quadrimestral da Pós-Graduação Stricto Sensu em Direito Processual da UERJ

Patrono: José Carlos Barbosa Moreira. ISSN 1982-7636. pp. 118-149

www.redp.uerj.br

ORLANDI, Renzo. Nota introduttiva. La ricerca della notizia di reato da parte dell'accusatore, Criminalia, 2011, p. 437 s.

ORLANDI, Renzo. Inchieste preparatorie nei procedimenti di criminalità organizzata: una riedizione dell'inquisitio generalis?, Rivista italiana di diritto e procedura penale, 1996, p. $591 \mathrm{~s}$.

PALAZZO, Francesco. Nel dedalo delle riforme prossime e venture, Rivista italiana di diritto e procedura penale, 2014, p. $1706 \mathrm{~s}$.

PRADO, Geraldo. Prova penal e sistema de controles epistêmicos. A quebra da cadeia de custódia das provas obtidas por métodos ocultos. São Paulo: Marcial Pons, 2014.

PROCURA DELLA REPUBBLICA DI TORINO, Circolare 10 gennaio 2007, numero 50 ("Maddalena"), Questione giustizia, 2007, 619 s.

QUATTROCOLO, Serena. Esiguità del fatto e regole per l'esercizio dell'azione penale, Napoli: Jovene, 2004.

RIVELLO, Pier P. Un intervento della Corte Costituzionale sul delicato problema dell'archiviazione per l'inidoneità degli elementi acquisiti nelle indagini preliminari a sostenere l'accusa in giudizio, La difesa penale, 1991, p. 62 s.

ROCCO, Alfredo. Sulla delega al Governo del Re della facoltà di emendare il Codice penale, il Codice di procedura penale, le leggi sull'Ordinamento giudiziario e di apportare nuove modificazioni e aggiunte al Codice Civile. Discorso pronunciato alla Camera dei Deputati nella tornata del 27 maggio 1925, Roma, Tip. della Camera dei Deputati 1925, p. 29-30. O texto consta também em: ROCCO, Alfredo. Discorsi parlamentari, com artigo de VASSALLI, Giuliano, Bologna: il Mulino, 2005, p. 192-3.

RUGGIERI, Francesca. Il principio di obbligatorietà dell'azione penale oggi: confini e prospettive, Criminalia, 2010, p. $301 \mathrm{~s}$.

SANTALUCIA, Giuseppe. Il potere del pubblico ministero di ricerca delle notizie di reato tra principi costituzionali e legge processuale, Rivista italiana di diritto e procedura penale, 2002, $150 \mathrm{~s}$.

SILVA, Edimar Carmo da; URANI, Marcelo Fernandez. Manual de Direito Processual Penal Acusatório. Doutrina e Jurisprudência. Curitiba: Juruá, 2013.

SILVA, Eduardo Araujo da. Ação Penal Pública: princípio da oportunidade regrada. $2^{\mathrm{a}}$ ed. São Paulo: Atlas, 2000.

TRANCHINA, Giovanni. Il pubblico ministero "ricercatore" di notizie di reato: una figura 
Revista Eletrônica de Direito Processual - REDP.

Rio de Janeiro. Ano 11. Volume 18. Número 1. Janeiro a Abril de 2017

Periódico Quadrimestral da Pós-Graduação Stricto Sensu em Direito Processual da UERJ Patrono: José Carlos Barbosa Moreira. ISSN 1982-7636. pp. 118-149

www.redp.uerj.br

poco rassicurante per il nostro sistema, Legislazione penale, 1986, $313 \mathrm{~s}$.

TRANCHINA, Giovanni. Ruoli naturali ed innaturali del giudice nel nuovo processo penale, Indice penale, 1989, $621 \mathrm{~s}$.

VASCONCELlOS, Vinicius G. Barganha e Justiça Criminal Negocial. São Paulo: IBCCRIM, 2015.

VASCONCELLOS, Vinicius G.; CAPPARELLI, Bruna. Barganha no processo penal italiano: análise crítica do patteggiamento e das alternativas procedimentais na justiça criminal. Revista Eletrônica de Direito Processual, vol. 15, p. 435-453, jan./jun. 2015. https://doi.org/10.12957/redp.2015.16880

VICOLI, Daniele. Criteri di priorità e meccanismi sospensivi: un difficile connubio in tema di accelerazione dei tempi processuali - Sezione seconda: Un mosaico normativo dagli incerti esiti applicativi. In: MAZZA, Oliviero; VIGANO', Francesco (org.). Misure urgenti in materia di sicurezza pubblica (d.l. 23 maggio 2008, n. 92 conv. in legge 24 luglio 2008, n. 125), Torino: Giappichelli, 2008, p. 371 - 399.

VICOLI, Daniele. Scelte del pubblico ministero nella trattazione delle notizie di reato e art. 112 cost.: un tentativo di razionalizzazione, Rivista italiana di diritto e procedura penale, 2003, p. $251 \mathrm{~s}$.

VICOLI, Daniele. L'esperienza dei criteri di priorità nell'esercizio dell'azione penale: realtà e prospettive. In: DI CHIARA, Giuseppe (org.), Il processo penale tra politiche della sicurezza e nuovi garantismi, Torino: Giappichelli, 2003, p. 225-262.

VIOLANTE, Luciano. Controllo di legalità, Cassazione penale, 2010, p. 879 s.

VOENA, Giovanni. Attività investigativa ed indagini preliminari, In: SIRACUSANO, Delfino (org.), Le nuove disposizioni sul processo penale, Atti del convegno di Perugia 14-15 aprile 1988, Padova: Cedam, 1989, p. 29 s.

VITALONE, Claudio. La funzione d'accusa tra obbligatorietà e discrezionalità. In: GAITO, Alfredo (org.). Accusa penale e ruolo del pubblico ministero: atti del Convegno: Perugia, 20-21 aprile 1990, Napoli: Jovene, 1991, p. 294.

ZAGREBELSKY, Vladimiro. Stabilire le priorità nell'esercizio obbligatorio dell'azione penale. In: FILIPPI, Camilla (org.), Il pubblico ministero oggi, Milano: Giuffrè, 1994, p. $101 \mathrm{~s}$.

ZAPPULLA, Angelo. Notizia di reato, Annali Enc. Dir., 2012, vol. IV, p. 890 s. 